\title{
Potential economic and environmental benefits from the interconnection of the Greek islands
}

\section{Eleni Zafeiratou* and Catalina Spataru}

\author{
Energy Institute, \\ UCL, \\ Central House, 14 Upper Woburn Place, \\ London WC1H 0NN, UK \\ Email: e.zafeiratou@ucl.ac.uk \\ Email:c.spataru@ucl.ac.uk \\ *Corresponding author
}

\begin{abstract}
Greece consists of 58 non-interconnected islands, located mainly in the Aegean Sea. Electricity is supplied to this region by 32 autonomous power systems (APS) using heavy fuel oil or diesel power generators. A number of interconnections between the islands and the national grid system have been scheduled for the upcoming years. In this paper, we analyse the economic and environmental benefits following the interconnections. It was concluded that Greece could save between 2015 and 2040, from 9.73 to 17.82 billion Euros, subject to fuel price costs and demand growth. These amounts are charged to the Greek power customers through a cross subsidisation policy known as public service obligation. Additionally, avoided costs for APS upgrade, range between 2.63 and 1.80 billion Euros. Interconnectors will also reduce the carbon footprint in the area by $51.1 \%-65.5 \%$ compared to the scenario of preserving APS. This is attributed mainly to renewable energy development reaching proportions of $84.7 \%-119 \%$ of the total power demand by 2040 .
\end{abstract}

Keywords: autonomous power systems; carbon emissions; Greek islands; interconnections; public service obligation; projections; renewable energy; wind energy; submarine cables; energy scenarios.

Reference to this paper should be made as follows: Zafeiratou, E. and Spataru, C. (xxxx) 'Potential economic and environmental benefits from the interconnection of the Greek islands', Int. J. Global Warming, Vol. X, No. Y, pp.xxx-xxx.

Biographical notes: Eleni Zafeiratou graduated as a Civil Engineer with an MEng diploma from the National Technical University of Athens in 2011. In 2013 she received her MSc in Environmental Systems Engineering from the University College London (UCL) and currently she is working towards her $\mathrm{PhD}$ at the UCL Energy institute. She has been working in parallel in various wind and solar energy projects, in buildings retrofits and as a research assistant. Her areas of research span through: autonomous power systems in islands, future energy scenarios, renewable energy systems, energy planning, energy management and conservation.

Catalina Spataru is a Lecturer in Energy Systems and Networks at UCL Energy Institute, course director for the MRes Energy Demand Studies (http://www.bartlett.ucl.ac.uk/energy/programmes/postgraduate/mres-energydemand-studies). She specialises in energy systems modelling and energy networks, making several contributions to the understanding of whole energy system. She is the regional representative of the IEEE Women in Power 
(Region 8 - Europe) and acted as a scientific chair for a number of international conferences. Currently she is leading the multi-disciplinary group Energy Space Time Group at UCL (https://www.bartlett.ucl.ac.uk/energy/research/ themes/energy-space-time).

This paper is a revised and expanded version of a paper entitled 'Potential environmental and economic benefits from the interconnection of the Greek islands' presented at Global Conference on Global Warming (GCGW), Athens, 24-27 May 2015.

\section{Introduction}

\subsection{Overview of the Greek non interconnected electrical system}

The Greek electricity system consists of the national grid system (NGS) and the noninterconnected system. The non-interconnected system comprises 58 islands, having a total population of 1,115,284 (Hellenic Statistical Authority, 2011). These islands are grouped in three regions: South Aegean including Cyclades and Dodecanese islands, North Aegean and Crete (Figure 1). Additionally, Skyros Island is included, which belongs to the Sporades complex and a number of other smaller islands.

Crete and Rhodes are the two largest and most populated non-interconnected islands (NII) occupying $66 \%$ of the total population. Together they generate more than $60 \%$ of the total energy in the non-interconnected part (Hellenic Electricity Distribution Network Operator, 2014). The main source of income for this region is tourism, followed by fishing, sailing and agriculture (Tsakiris, 2010).

Figure 1 Map of the non-interconnected Greek islands (see online version for colours)

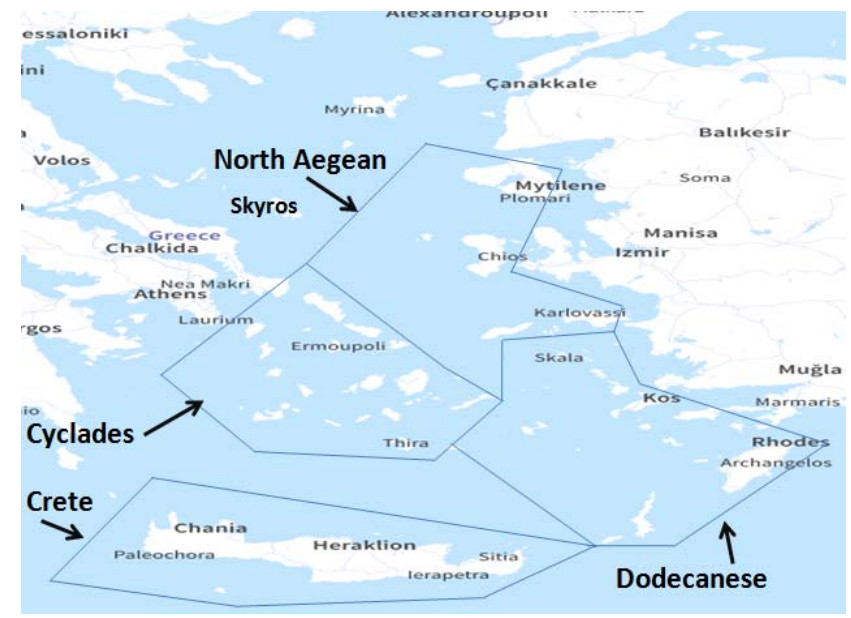


The Greek NII system is electrified by 32 autonomous power stations (APS), belonging to the Greek Public Power Corporation (PPC) (Regulatory Authority for Energy, 2013). Several islands are already interconnected with neighbour islands allowing power supply from the same units and enabling power distribution among them. Benefits are identified only at an island level due to limitations in the power grid which requires upgrades in the upcoming years.

All Greek NII are considered as isolated micro-systems, except Crete and Rhodes, which are excluded from the Art. 26, Directive 2003/54/EC (European Union, 2003; Panteri and Sardi, 2010) due to their relatively high level of electricity consumption. Micro-systems were not imposed to promote energy liberalisation and the main power producer and supplier has remained PPC. The final Non-Interconnected Islands Code published in February of 2014 under the Law 4001/2011 provisions, aims to improve the current energy system in the NII and supports liberalisation by annulling the current monopoly of PPC. Also it intends to reduce high costs of APS, guarantee the secure and smooth operation of the system, and increase renewable energy share in the local energy market (Hellenic Republic, 2014a).

The Hellenic Electricity Distribution Network Operator (HEDNO) or DEDDHE according to the Greek abbreviation is the Island System Operator (ISO), being responsible for the operation, maintenance and upgrade of local grids. HEDNO is a subsidiary of PPC which was formerly the ISO being in charge of all the installed power plants on the islands, with the exception of renewable energy sources (RES) installations (Iliadou, 2009). Since 2011, following the unbundling imposed by Law 4001/2011, HEDNO became an independent body in charge of the operation of the distribution network in Greece under the 2009/72/EC Directive.

The primary electricity source in the non-interconnected islands is heavy fuel oil (HFO) or diesel. The total capacity of oil-fired power generators is 1,753.24 MW, while renewable energy capacity reached 452.15 MW in 2014 (Hellenic Electricity Distribution Network Operator, 2014). In total, power generation in islands shares $11.23 \%$ of the total Greek electricity generation (Hellenic Electricity Distribution Network Operator, 2013a; Ministry of Reconstruction of Production Environment and Energy, (2015)). Diesel and heavy fuel oil power generators cause air pollution in the area with carbon dioxide emissions $\left(\mathrm{CO}_{2}\right)$ exceeding 21 million tonnes in the last five years. In the context of eliminating green house gas emissions by 2020 and 2030 under the EU energy framework for climate change (European Commission, 2009, 2014); Greece is imposed to improve its energy fuel mix and replace highly polluted resources as oil.

\subsection{Public service obligation policy}

Apart from the environmental impact, oil fuel prices and related taxes have been exceptionally increasing, reaching 177.34 $\mathrm{MWh}^{1}$ on average in 2013 (Hellenic Republic, 2014c). The total mean cost including also stable costs was estimated to be $230.83 € / \mathrm{MWh}$ for the same year, based on data recorded by HEDNO and the Regulatory Authority for Energy in Greece (RAE) (Table 4). In contrast, the generalised average electricity price (PGAE) in the mainland was much lower: $70.5 € / \mathrm{MWh}$.

Extra costs are being isomerised between consumers in the mainland and in the NII, through their monthly electricity bills, as a result of the public service obligation (PSO). PSO is a subsidisation policy, which has been established initially by Law 2773/1999 and 
amended with the current Law 4001/2011 (particularly articles 55 and 56 which include the provisions of this policy) (Hellenic Republic, 2011a). The Law 4067/2012 (Hellenic Republic, 2012) estimated the charges of the PSO for 2009-2012. Based on these legislation frameworks, as well as several ministerial decisions (Hellenic Republic, 2007, 2010, 2011b) RAE published the decision 14/2014 which introduced the calculation method for estimating precisely the PSO from the NII (Regulatory Authority for Energy, 2014).

$$
P S O=\sum_{n}\left[\left(\operatorname{CostNII}_{n}-P G A E\right) * G N I I_{n}+\text { PRESNII }_{n} * \operatorname{GRES}_{n}-\text { CharNII }_{n}\right]
$$

where

$\begin{array}{ll}\text { PSO } & \text { public service obligation } \\ n & \text { autonomous power systems } \\ \text { CostNII } & \text { thermal power generation cost in each APS } \\ \text { PGAE } & \text { generalised average electricity price } \\ \text { GNII } & \text { thermal power generation in every APS } \\ \text { PRESNII } & \text { average variable cost for NII - PGAE } \\ \text { GRES } & \text { power generation from RES in each APS } \\ \text { CharNII } & \text { charges that electricity consumers in NII pay. }\end{array}$

The total public service obligation which is the complete additional cost for conventional and renewable generation in the islands was calculated from RAE to be approximately 771.2 million Euros for 2013 as presented in Table 1 (Hellenic Republic, 2014d). The extra cost between the non-interconnected part and the interconnected is included in the consumers' electricity bills for all residents in Greece. For the residential and commercial sectors, costs vary from $6.99 € / \mathrm{MWh}$ to $44.88 € / \mathrm{MWh}$ depending on the power consumption of each premise. For other users: industrial and agricultural sectors the amount varies from 4.14 $€ / \mathrm{MWh}$ to $18.24 € / \mathrm{MWh}$, according to the latest data published by the Regulatory Authority for Energy for 2012. These figures show a 35 times increase compared to 2011, particularly for the low level power consumption category.

The above policy may have an adverse impact to the Greek environment and economy. Since the Government provides subsidies to the islands consumers; there is no motivation from their side to move towards energy efficiency and sustainable energy development solutions.

Several solutions have been proposed in order to eliminate the operation of the autonomous power systems in the NII, which beyond the pure economic effect, they cause aesthetic disturbances and environmental impact as they are usually located close to residential neighbourhoods. The two main plans for eliminating local thermal power generation consist in: integration of energy storage technologies e.g. batteries in combination with clean energy technologies or installation of submarine interconnections between islands and the national power system. Both proposals aim to boost renewable energy generation by eliminating technical constraints in autonomous power grids. 
Table 1 Power generation data, power costs and the public service obligation for 2013

\begin{tabular}{|c|c|c|c|c|c|}
\hline$A P S$ & $\begin{array}{c}\text { Power } \\
\text { generation } \\
(M W h)\end{array}$ & $\begin{array}{c}\text { Thermal } \\
\text { power } \\
\text { generation } \\
(\%)\end{array}$ & $\begin{array}{l}\text { Renewable } \\
\text { power } \\
\text { generation } \\
(\%)\end{array}$ & $\begin{array}{c}\text { Cost of } \\
\text { thermal power } \\
\text { generation } \\
(€ / M W h)\end{array}$ & $\begin{array}{c}\text { Public service } \\
\text { obligation } \\
\text { (Mil€) }\end{array}$ \\
\hline Crete & $2,795,888.0$ & $82.83 \%$ & $17.17 \%$ & 223.6 & 388.559 \\
\hline Rhodes & $859,705.2$ & $83.51 \%$ & $16.49 \%$ & 243.41 & 121.56 \\
\hline Lesvos & $236,623.6$ & $81.28 \%$ & $18.72 \%$ & 196.99 & 33.976 \\
\hline Kos-Kalymnos & $398,314.3$ & $88.72 \%$ & $11.28 \%$ & 171.93 & 34.345 \\
\hline Lemnos & $47,882.5$ & $88.02 \%$ & $11.98 \%$ & 242.85 & 9.478 \\
\hline Skyros & $11,725.6$ & $86.96 \%$ & $13.04 \%$ & 400.8 & 4.702 \\
\hline Paros & $201,196.8$ & $84.91 \%$ & $15.09 \%$ & 190.34 & 21.701 \\
\hline Chios & $155,725.6$ & $86.25 \%$ & $13.75 \%$ & 178.25 & 20.453 \\
\hline Siros & $79,430.1$ & $94.64 \%$ & $5.36 \%$ & 226.58 & 13.967 \\
\hline Samos & $121,739.3$ & $77.16 \%$ & $22.84 \%$ & 222.43 & 18.657 \\
\hline Karpathos & $40,371.6$ & $88.72 \%$ & $11.28 \%$ & 294.4 & 7.464 \\
\hline Mykonos & $152,380.7$ & $97.53 \%$ & $2.47 \%$ & 345.75 & 29.625 \\
\hline Agios Eustratios & 856.6 & $100.00 \%$ & $0 \%$ & 420.82 & 0.37 \\
\hline Thira & $163,346.7$ & $99.72 \%$ & $0.28 \%$ & 268.95 & 23.165 \\
\hline Ikaria & $23,522.3$ & $89.85 \%$ & $10.15 \%$ & 364.99 & 7.396 \\
\hline Agathonisi & 456.1 & $100.00 \%$ & $0 \%$ & 704.86 & 0.403 \\
\hline Anafi & $1,248.7$ & $100.00 \%$ & $0 \%$ & 500.43 & 0.499 \\
\hline Donousa & $3,182.0$ & $100.00 \%$ & $0 \%$ & 754.79 & 0.468 \\
\hline Ereikousa & 534.6 & $100.00 \%$ & $0 \%$ & 801.42 & 0.543 \\
\hline Megisti & $7,214.8$ & $100.00 \%$ & $0 \%$ & 527.16 & 1.356 \\
\hline Othoni & $7,089.5$ & $100.00 \%$ & $0 \%$ & 656.59 & 0.367 \\
\hline Kythnos & $16,557.1$ & $94.09 \%$ & $5.91 \%$ & 405.36 & 2.541 \\
\hline Serifos & $11,725.6$ & $97.57 \%$ & $2.43 \%$ & 419.62 & 2.582 \\
\hline Sifnos & $16,557.1$ & $94.09 \%$ & $5.91 \%$ & 378.95 & 4.943 \\
\hline Patmos & $16,128.7$ & $88.00 \%$ & $12.00 \%$ & 367.71 & 4.586 \\
\hline Astipalaia & $6,118.7$ & $90.93 \%$ & $9.07 \%$ & 411.74 & 2.105 \\
\hline Milos & $23,522.3$ & $89.85 \%$ & $10.15 \%$ & 64.99 & 7.998 \\
\hline Arkioi & 328.8 & $100.00 \%$ & $0 \%$ & 948 & 0.273 \\
\hline Gavdos & 444.4 & $100.00 \%$ & $0 \%$ & 539.21 & 0.219 \\
\hline Antikythera & 238.0 & $100.00 \%$ & $0 \%$ & 1265.39 & 0.286 \\
\hline Amorgos & $9,238.0$ & $94.84 \%$ & $5.16 \%$ & 374.21 & 2.624 \\
\hline Symi & $14,116.2$ & $98.04 \%$ & $1.96 \%$ & 349.63 & 3.979 \\
\hline Total & $5,423,409.5$ & & & & \\
\hline
\end{tabular}

Source: Hellenic Republic (2014d) 


\section{Future plans for interconnection in the Greek Islands}

This section provides an overview of future interconnections in the NII. Academic and governmental publications have discussed the direct interconnection of $z 1$ istare The future interconnections that have been investigated are:

1 interconnection of the Cycladic islands (partially) with the national grid system

2 expansion of Cyclades interconnection

3 interconnection of Crete with the NGS

4 interconnection of North Aegean (Chios, Lesvos, Ikaria, Samos, Lemnos) with the NGS

5 interconnection of Dodecanese islands (among them)

6 interconnection of the NGS, Crete and Dodecanese islands

7 Skyros island interconnection with the NGS.

\subsection{Interconnection of the Cycladic Islands and the Greek national grid system (Independent Power Transmission Operator, 2013)}

The only scheduled interconnection project in the Greek islands is the connection part of the Cyclades region. In September 2014, the Minister of Environment, Energy and Climate Change (former designation reference) approved the national public financial support for this project (Independent Power Transmission Operator, 2014a). The first stage of this project started in early 2015 and it is estimated to complete by 2017 without taking into account possible delays. The Cyclades interconnection is split in three different stages as presented in the Independent Power Transmission Operator (2014b).

- Stage 1 includes the following connections with the use of submarine alternating current $(\mathrm{AC}) 150 \mathrm{kV}$ cables:

1 Syros connection to Lavrio's High Voltage (HV) substation in the Greek mainland (108 km length)

2 Syros with Tinos island which was previously connected with the mainland via Evia island (33 km length)

3 Syros with Paros island (46 km length)

4 Syros with Mykonos island (35km length).

- Stage 2 of this project includes extension of the previous interconnection using also AC $150 \mathrm{kV}$ cables.

1 Paros and Naxos islands will be interconnected $(7.6 \mathrm{~km})$

2 Naxos will be connected with Mykonos (40 km).

- Stage 3 includes the reinforcement of the cable connecting Lavrio and Syros with the submersion of a second AC cable between the substations of these two locations. The projected Cyclades interconnection is depicted in Figure 2 which shows the development of a bronchus among the four islands as well as the connection between Syros and NGS via two different routes. 


\subsection{Expansion of Cyclades interconnection (National Technical University of} Athens, 2008)

Following the immersion of the second cable between Syros and Lavrio, there are plans to expand this interconnection from Paros-Naxos to Ios and Thira (Santorini) islands with AC submarine cables of nominal capacity140 $\mathrm{MVA}^{2}$. The second phase of this expansion proposes the interconnection of Ikaria and Samos islands with AC submarine cables to Mykonos. In this study, we consider the interconnection of these islands through the North Aegean interconnection plan (Section 2.4).

The second project for Cycladic islands includes also the interconnection of Evia and Andros islands with the Greek mainland. These two islands are already interconnected with the national grid system. The new planned interconnection with a transmission capacity equal to $2 * 350 \mathrm{MW}$ will allow higher renewable energy integration into these islands, as both islands are characterised by extremely high wind potential (Regulatory Authority for Energy et al., 2008).

\subsection{Interconnection of Crete with the mainland (Regulatory Authority for Energy et al., 2011)}

Initial studies for the interconnection of Crete with the mainland were completed in 2011. The expansion of this project is included in the ten year plan for development of the transmission system for 2014 to 2023 . Nevertheless, as this project depends principally on private funds, aiming to exploit the renewable energy potential of Crete, it is doubtful whether it will be implemented in the near future, given the current volatile economic circumstances in Greece. Further research is required in terms of technical analysis for selecting the optimum interconnection route, considering cost and power grid stability and environmental impact. In that sense, three scenarios and four options (Scenario B includes two interconnection options) have been proposed, incorporating different interconnection plans.

Scenario A: Crete will be interconnected with Peloponnese (South Greece), with Direct Current (DC) cables, as the route length exceeds $80 \mathrm{~km}$, the practically maximum limit for AC cables. The interconnection will consist of partially submarine cables (Korakia town in Crete to Peloponnese) and partially aerial constructions, (Monemvasia Town to Megalopoli Town), with a total capacity of $2 * 350 \mathrm{MW}$ and $370 \mathrm{~km}$ length.

Scenario B suggests two options: B1: Crete will be connected with a substation west to Athens with DC cables, partially submarine including also aerial and underground parts depending on the location. The cable will have a total transmission capacity of $2 * 500 \mathrm{MW}$ and $380 \mathrm{~km}$ length. This option has as a starting point the substation in Korakia town. Option B2: the interconnection of Crete with Attica and Peloponnese with two DC cables with total nominal capacity of $2 * 500 \mathrm{MW}$. The first connection starts from Korakia to Attica and will consist of submarine cables with a total length $380 \mathrm{~km}$. The second cable will start from a connection point in the area of Chania in North-West Crete and will end in Monemvasia in Peloponnese with a total length of $250 \mathrm{~km}$.

Scenario $C$ : The only difference between Scenario $C$ and Scenario B2 is the size of the DC unipolar connector, which will have a larger transmission capacity of $2 * 1,000 \mathrm{MW}$ 


\subsection{Interconnection of North Aegean with the national grid system (National Technical University of Athens, 2008)}

Stage 1 Includes the interconnection between Lesvos and Chios islands and the main power system. The predominant scenario according to the National Technical University of Athens consists of a: double circuit with DC 2*350 MW cables from Aliveri town in Evia Island, (which is already interconnected) to Chios Island. The length of the submarine cable will be $160 \mathrm{~km}$ including $20 \mathrm{~km}$ underground cable. Chios and Lesvos will be interconnected with double circuit DC $2 * 250 \mathrm{MW}$ cables of total length $90 \mathrm{~km}$.

Stage 2 Proposes the expansion of the interconnection from Chios island to Ikaria and Samos islands. The interconnection length between Chios and Ikaria islands is $110 \mathrm{~km}$, using DC cables $2 * 150 \mathrm{MW}$. This scenario inhibits the expansion of over-ground grid installations on the island that cause aesthetic disturbances in the landscape. Ikaria with Samos islands will be interconnected with AC cables $2 * 140$ MVA having a total length of $80 \mathrm{~km}$.

Stage 3 Plans the interconnection of Lemnos island from Lesvos an intermediate substation in Agios Eustratios island. (hi) proposal splits the $120 \mathrm{~km} \mathrm{AC} \mathrm{cable}$ of nominal capacity $2 * 140$ MVA, from Lesvos to Lemnos in: $80 \mathrm{~km}$ between Lemnos and Lesvos and $40 \mathrm{~km}$ between Agios Eustratios and Lemnos.

\subsection{Interconnection of Dodecanese islands (National Technical University of Athens, 2008)}

This project includes the interconnection of Rhodes, the largest island in Dodecanese region with Kos and Kalymnos islands via two smaller northern islands: Tilos and Nisyros. The interconnection will be designed as follow: Rhodes to Tilos $50 \mathrm{~km}$ length, Tilos to Nisyros $25 \mathrm{~km}$ length and Nisyros to Kos $25 \mathrm{~km}$ length with AC cables. Upon interconnection's completion, the APS of Kos-Kalymnos will shut down and Rhodes, Kos and Kalymnos will receive electricity from the Rhodes' power station. If the geothermal power station in Nisyros island is completed and functional, part of the islands' power requirements will be covered by geothermal energy from Nisyros as well as conventional power from the APS in Rhodes, pending their interconnection with the main system.

\subsection{Interconnection of national grid system - Crete and Dodecanese Islands (National Technical University of Athens, 2008)}

This includes the interconnection of Dodecanese islands with Crete subsequent to the interconnection of Crete with the NGS. The interconnection will be completed with two circuits, AC cables with transmission capacity equal to $2 * 280$ MVA. Enhancement of a third cable will be necessary at a later stage. The interconnection route will include the following destinations: Crete, Kasos, Karpathos and Rhodes. Crete will be connected to Kasos (70 km length), Kasos to Karpathos (75 km length), Karpathos to Rhodes (85 km length). The interconnection will include also a medium voltage over-ground grid between two substations in Crete (Vai, Atherinolakos) of total length $30 \mathrm{~km}$. 
2.7 Interconnection of Skyros with the mainland (Papadopoulos et al., 2006; Hellenic Electricity Distribution Network Operator, 2010)

Skyros and Evia Island will be interconnected with DC $(2+1) * 250 \mathrm{MW}$ cables through a $154 \mathrm{~km}$ length connection, including submarine and underground cables, in order to transfer energy from large scale licensed wind projects, ready to be implemented in the area of Skyros

Figure 2 presents the future planned interconnections among the Greek islands and the national power system.

Figure 2 The interconnection plan of the NII in the Aegean Sea (see online version for colours)

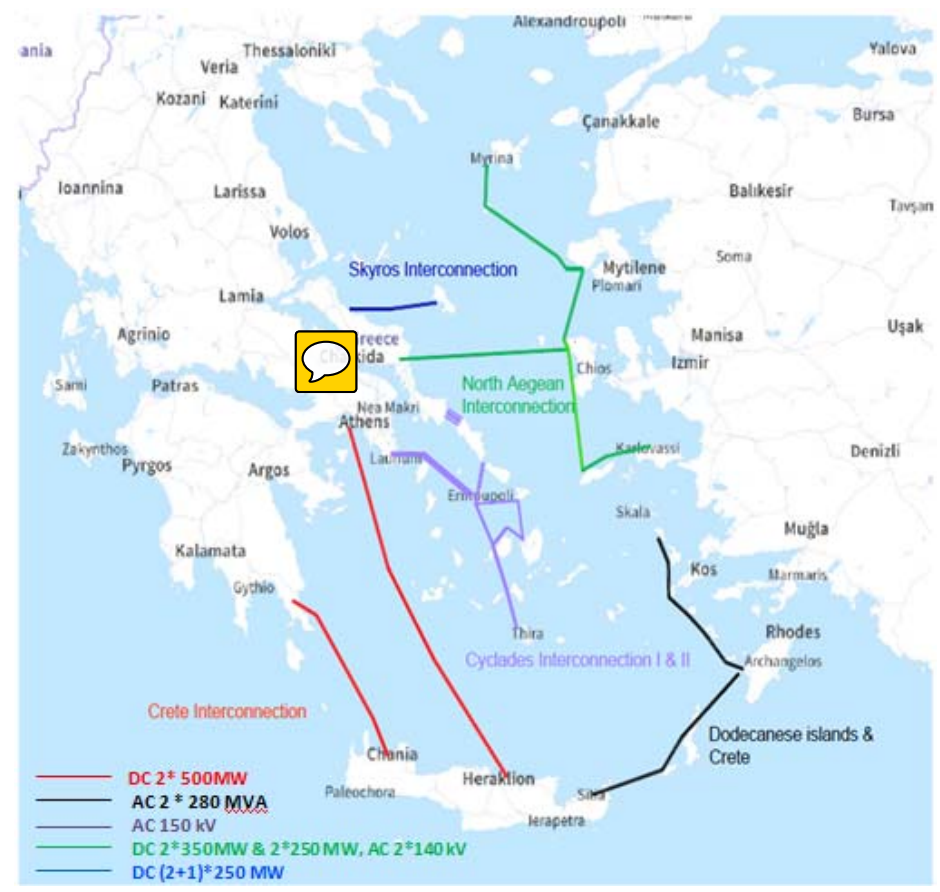

\subsection{Interconnections' costs}

Table 2 presents costs stemming from the interconnection scenarios discussed in the previous section. The values are taken from the following sources: National Technical University of Athens (2008); Regulatory Authority for Energy et al. (2011) and Independent Power Transmission Operator (2013) and adjusted to 2013 taking into account the inflation indicators statistics (Bank of Greece, 2015). The most expensive part of such installations is the submarine cable; in most interconnections this accounts for $80-85 \%$ of the total budget estimation. For Crete three scenarios are presented. We assumed that Scenario B1 is the optimal case as it is reasonable costly and it provides a minimum of energy security. The alternative interconnection between Crete and Monemvasia can possibly delay the project due to difficulties in expanding $\mathrm{HV}$ and MV 
over-ground network in Peloponnese. The most expensive region to become interconnected is North Aegean due to high substations' costs and other equipment in Chios and Lesvos islands. The total cost is estimated to be approximately 3.44 billion Euros.

Table 2 Total cost for the interconnection of the Greek islands

\begin{tabular}{|c|c|c|c|c|}
\hline Region to be interconnected & $\begin{array}{c}\text { Cost of } \\
\text { submarine } \\
\text { cable (Mil€) }\end{array}$ & $\begin{array}{c}\text { Cost of } \\
\text { over-ground } \\
\text { cable (Mile) }\end{array}$ & $\begin{array}{c}\text { Cost of substations } \\
\text { and other } \\
\text { equipment (Mil€) }\end{array}$ & $\begin{array}{l}\text { Total cost } \\
\quad \text { (Mile) }\end{array}$ \\
\hline Cycladic islands & 348 & & 53 & 401 \\
\hline Stage A & 203 & & 48 & 251 \\
\hline Stage B & 35 & & 5 & 40 \\
\hline Stage C & 110 & & & 110 \\
\hline $\begin{array}{l}\text { Expansion of Cyclades } \\
\text { interconnection (IOS and Thira) }\end{array}$ & 226 & 1.85 & 28.4 & 256.2 \\
\hline Crete & & & & 0 \\
\hline Scenario A & 310.8 & 30 & 207.2 & 548 \\
\hline Scenario B & 566.8 & 0 & 248.7 & 815.5 \\
\hline Scenario C & $1,031.5$ & 47.6 & 373 & $1,452.1$ \\
\hline North Aegean & 692.2 & 75.3 & 347.6 & $1,115.1$ \\
\hline Chios and Lesvos & 273.2 & 75.3 & 313.1 & 661.6 \\
\hline Chios and Ikaria. Ikaria and Samos & 224.2 & & 18.5 & 242.7 \\
\hline Lesvos and Lemnos & 194.8 & & 16 & 210.8 \\
\hline $\begin{array}{l}\text { Dodecanese islands } \\
\text { (among them) }\end{array}$ & 225.9 & & 18.5 & 244.4 \\
\hline Rhodes and Tilos & 92.7 & & 10.3 & 103 \\
\hline Tilos and Nisyros & 46.3 & & 11.6 & 57.9 \\
\hline Nisyros and Kos & 46.3 & & 11.6 & 57.9 \\
\hline Crete and Dodecanese islands & 370.2 & 12.5 & 67.8 & 450.5 \\
\hline Crete and Kasos & 129 & 12.5 & 17.8 & 159.3 \\
\hline Kasos and Karpathos & 83.5 & & 18.3 & 101.8 \\
\hline Karpathos and Rhodes & 157.7 & & 31.7 & 189.4 \\
\hline Skyros island & 103.2 & 13.5 & 46.4 & 163.1 \\
\hline $\begin{array}{l}\text { Total cost for the interconnection } \\
\text { of all the islands }\end{array}$ & \multicolumn{4}{|c|}{ 3,445.91 Mil $€$} \\
\hline
\end{tabular}

\section{Methodology}

\subsection{Energy scenarios}

Four scenarios from 2015 to 2040 were developed to assess future electricity trends and costs in the Aegean Sea. The scenarios are based on different energy and economic factors in order to explore the future power system in the candidate interconnected Srete, Rhodes, Kos-Kalymnos, Karpathos, Lesvos, Chios, Samos, Lemnos, 
Agios Eustratios, Paros, Syros, Mykonos, Thira, Skyros and Ikaria. These scenarios provide different options for estimating future power generation, maintenance and other stable costs of oil-fired units located on the isolated power system for two cases:

a business as usual (BAU) assuming continuation of APS operation

b interconnection of islands.

The interconnection schedule depicted in Figure 4 is based on the strategy presented in Section 2 .

- Scenario A (Figure 3): Scenario A assumes relatively high growth in energy demand by 2040 , as a consequence of economic recovery and increase in tourism levels. Scenario A is split in two sub-scenarios A1 and A2. Case 1 assumes rapid increase in oil-fuel prices following 2020. Case 2 is based on modest assumptions for lower increase in fuel prices as discussed below.

- Scenario B (Figure 3): Scenario B assumes lower growth in energy demand in the Aegean Sea, as a result of the past trends with the exception of Paros and Mykonos islands which are assumed to follow a different pathway and continue their past increasing trends. Scenario B is also divided in B1 and B2 based on the same fuel price assumptions.

Figure 3 Scenarios A (1 and 2) and B (1 and 2) (see online version for colours)

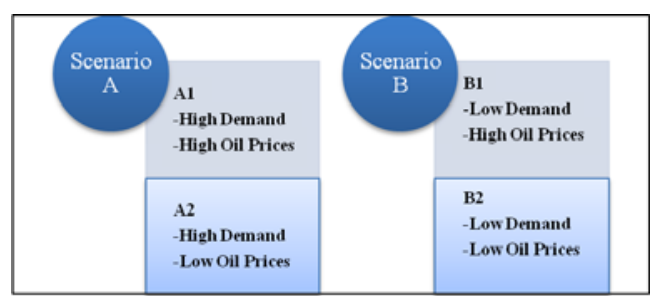

Figure 4 Islands' interconnection schedule (see online version for colours)

\begin{tabular}{|cccc|}
\hline Cyclades I II & $\begin{array}{c}\text { Cyclades } \\
\text { North } \\
\text { Aegean }\end{array}$ & $\begin{array}{l}\text { Crete and } \\
\text { Dodecanese } \\
\text { islands }\end{array}$ \\
\hline Crete & 2020 & Skyros & $\begin{array}{c}\text { Dodecanese } \\
\text { silands } \\
\text { among them }\end{array}$ \\
\hline
\end{tabular}

\subsection{Main assumptions}

\subsubsection{Growth factors}

In order to calculate costs until 2040 we estimated the annual average power generation prices from 2015 to 2040 . The projected power generation costs, in the interconnected part of Greece is assumed to grow by $2 \%$ every year, above the annual average inflation (National Technical University of Athens, 2008). Currently, the Greek inflation indicator experiences negative trends due to the extensive impacts of the financial crisis in Greece 
(Bank of Greece, 2015). On average 0.5\% increase rate was assumed, as a result of a few years of negative inflation and afterwards gradual progress in the economy.

Part of public service obligation costs is charged to carbon emissions from power stations located on the islands, as Greece is imposed to pay fees to the European Emissions Trading System (EU ETS) in case of excess of emissions levels, through directives 2003/87/EC and 2009/29/EC. The Greek PPC is the competent authority, participating in the EU ETS. In 2013, the PPC had to pay 14.74 million Euros for the additional emissions permits from thermal power plants in NII (Hellenic Republic, 2014c). Since the beginning of 2013, emissions acquired a subtitled cost of 25.30 $€ / \mathrm{tnCO}_{2}$. Due to the European economic recession as well as different environmental regulations among a number of EU members, this amount has been significantly reduced over the last two years (Argyriou, 2013), configuring a price of $6 € / \mathrm{tnCO}_{2}$ for the noninterconnected Greek area (Hellenic Republic, 2014b). However, increase trends have been assumed in the following years, with an annual rate of 5\% (National Technical University of Athens, 2006).

Table 3 Growth factor assumptions for costs' estimation

\begin{tabular}{lc}
\hline Assumptions & Growth factor (\%/annum) \\
\hline Inflation & $0.5 \%$ \\
Generalised average electricity price & $2 \%+0.5 \%$ \\
Fuel taxes and extra variable costs & $0.5 \%$ \\
$\mathrm{CO}_{2}$ emissions & $5 \%$ \\
\hline
\end{tabular}

\subsubsection{Fuel costs}

Currently in 2015, oil prices experience historically low levels with values equal to 372.4 $€ /$ tonne $(52.4 \$ / \mathrm{bbl})$ reduced by $50 \%$ compared to 2013 values of $767.5 € /$ tonne (108 $\$ /$ bbl) (US Energy Information Administration, 2016). The fuel prices up to 2040 were determined based on the assumptions made in the World Energy Outlook (2015) by the International Energy Agency (IEA), including two scenarios, illustrated in Figure 5. The Current Policies scenario assumes relatively high growth in oil prices based on the assumption of maintaining policies enacted as in mid-2015 and preserving the current oil demand levels worldwide. Low growth is reflected in the 450 scenario which depicts a pathway to the $2{ }^{\circ} \mathrm{C}$ climate goal driving the market equilibrium to lower costs.

Figure 5 Oil prices according to the high growth and low growth scenarios (Euros/tonne) ${ }^{3}$ (see online version for colours)

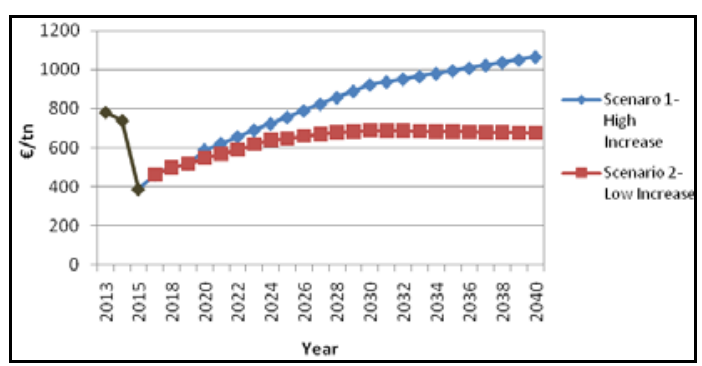

Source: IEA and OECD (2014) 
Potential economic and environmental benefits

Table 4 Technical characteristics of autonomous power stations

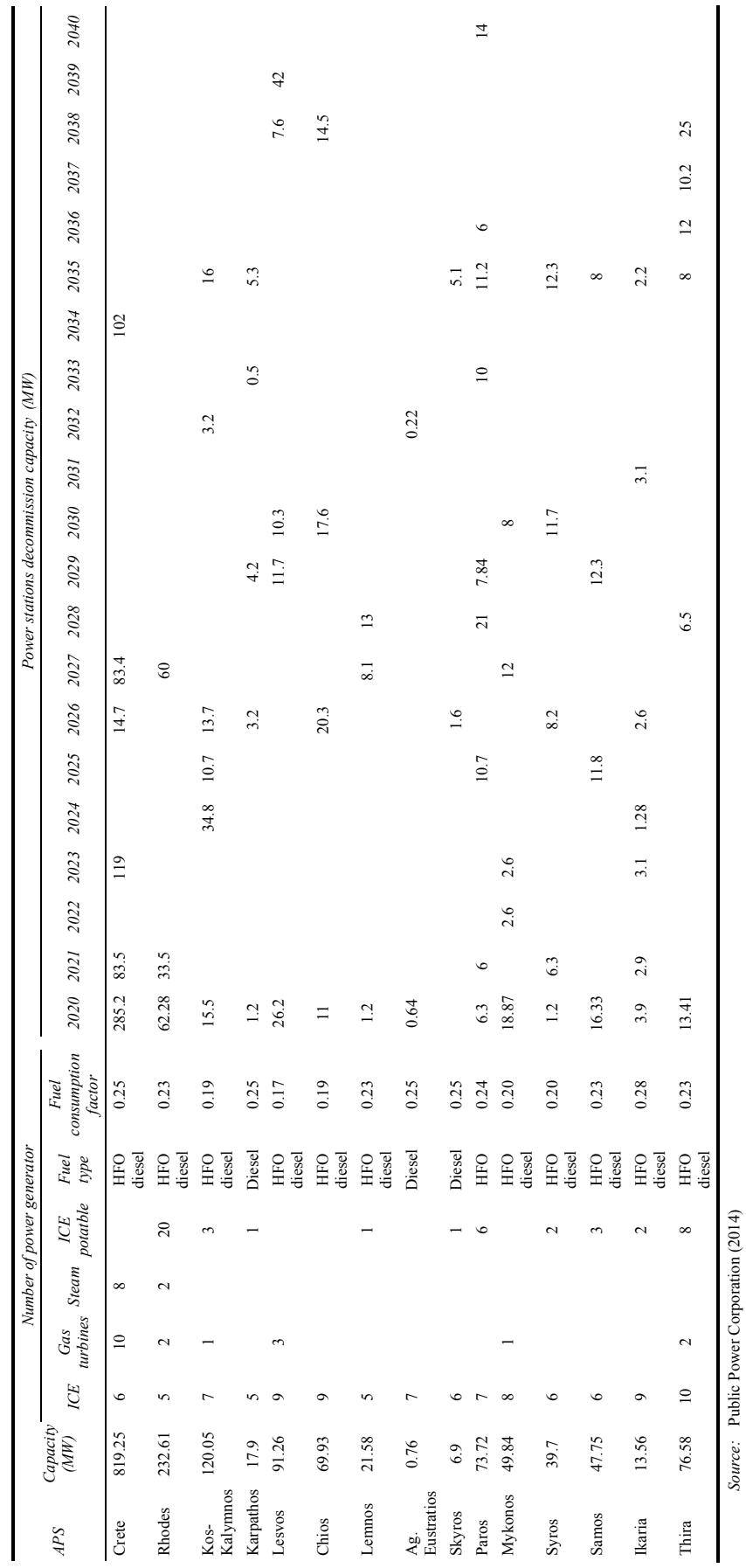




\subsubsection{Technical characteristics and costs}

Fuel consumption factor is diversified among each autonomous power system depending on power engine type, age and other attributes. Most power stations consume both diesel and heavy fuel oil, whereas Karpathos, Skyros and Agios Eustratios use exclusively diesel fuel. The two main types of engines are: internal combustion engines (ICE) available in various sizes and gas turbines with lower capital costs and speedily peak demand supply availability. Stream turbines and combined cycle engines operate only in Crete and Rhodes as they are utilised to serve mainly base loads. Table 4 presents the capacity of each APS as well as fuel consumption and decommission dates for units.

Table 4 provides a guideline for power stations upgrade according to the retirement schedule. Costs for new units are considered based on 2013 values and are presented in Table 5. Costs for the introduction of new units between 2015 and 2040 are indexed according to the inflation rate in order to reflect future costs.

Table 5 Costs for new power engines (Independent Power Transmission Operator, 2013)

\begin{tabular}{ll}
\hline Type & Cost \\
\hline ICE & 1.45 \\
Gas turbine & 0.49 \\
\hline
\end{tabular}

\subsubsection{Energy demand}

Energy demand was assumed to follow Scenario A and Scenario B trends. Scenario A (Figure 6) suggests overall high electricity growth based on projection factors included in the Final Report-Strategic Plan for the Interconnection of Non-Interconnected Islands to Regulatory Authority for Energy (2008) for Crete, Dodecanese and North Aegean Islands and in the Initial Ten Year Development Plan for the Transmission System (2014-2023) (Independent Power Transmission Operator, 2013), for the Cyclades interconnection. Scenario B presented in Figure 7 follows a statistical analysis approach based on the last 15 year data and assumes continuation of recession until 2020 which impacts electricity consumption. From 2020 to 2030 energy growth reverts to 2000-2008 levels; by 2040 energy use will double assuming economic prosperity.

Figure 6 Thermal power demand in NII from 2015 to 2040-scenario A (see online version for colours)

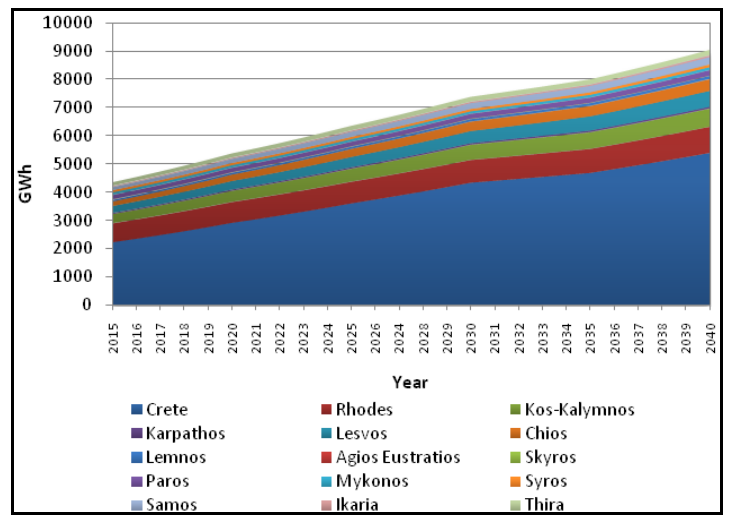


Figure 7 Thermal power demand in NII from 2015 to 2040-scenario B (see online version for colours)

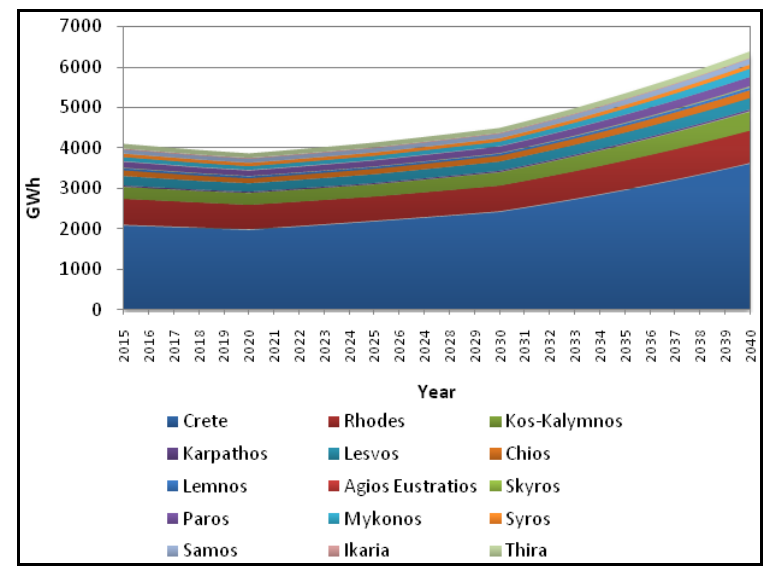

Scenario A is a high growth scenario without considering the economic crisis beyond 2015. Crete will experience the largest growth in energy demand in case A. This could be anticipated, since Crete has the highest level of population, tourism and tendency for energy growth in the non-interconnected part. Scenario B also assumes high levels for Crete, however in this case Mykonos and Kos will record the highest growth assuming continuation of past growth trends.

\subsubsection{Renewable energy growth}

Future renewable energy share was investigated in order to calculate sustainable power generation in the area. Renewable energy experienced rapid development (mainly solar) between 2009 and 2014 in both islands and mainland, with 16.8\% increase for wind energy while solar energy went through an unprecedented increase, growing 173 times (Hellenic Electricity Distribution Network Operator, 2013b) due to the feed-in tariff (FIT) mechanism which was established through 3468/2006 and 3851/2010 laws. Since 2013 the national subsidies and FIT have significantly decreased (Hellenic Republic, 2013; Hellenic Republic - Ministry of Environment Energy and Climate Change, 2013). As a consequence, an annual average growth in RES investments in islands equal to $1 \%$ per year (from 2013 levels) was considered, with a maximum restriction to $25 \%$. This can be considered realistic, given the fact that technical limitations continue to exist in small scale power systems as those operating on the islands and wind energy penetration is not permitted to exceed the limit of $30 \%$ of the hourly load demand to ensure the stability of the power grid from power cuts and abrupt frequency alterations (Hatziargyriou et al., 2012; Maroulis, 2013).

\subsection{Cost calculation}

Future costs have been estimated between 2015 and 2040 configuring the public service obligation policy in NII for Scenarios A1, 2 and Scenarios B1, 2 according to equation (1). In the calculation methodology costs were split in variable and stable costs. 
The year of 2013 was considered as the base year since it is the most recent year with available data.

Variable costs are expressed in MWh, including fuel costs diversified in each island according to power stations fuel consumption and additional variable costs. Fuel tax and $\mathrm{CO}_{2}$ emissions costs are considered common for all the islands included in the analysis.

$$
\begin{aligned}
\text { Variable costs }_{n} & =\text { Fuel costs } \\
& +\mathrm{CO}_{2} \text { cost }
\end{aligned}
$$

Fuel costs $=$ Consumption of power station $*$ Oil costs

Stable costs include remunerations, equipment and consumable materials, capital costs and others. They were initially expressed in MW of capacity and in the secondary process are expressed in MWh, in order to form total costs.

$$
\text { Stable costs }{ }_{n}=\text { Stable costs }_{n} *{\text { Installed } \text { capacity }_{n}+\text { New units costs }}_{n}
$$

Taking into consideration the diversification between stable and variable costs, PSO was calculated from 2015 to 2040 as presented below:

$$
\begin{aligned}
P S O=\sum_{n}\{ & {\left[\left(\text { Variable cost }_{n}+\text { Stable costs }_{n}\right)-P G A E\right] * G N I I_{n} } \\
& +\left[\left(\frac{\sum_{n} \text { Variable costs }_{n}}{n}\right)-P G A E\right] \\
& \left.* G R E S_{n}-\text { Factor for interconnected system use } \text { HNII }_{n}\right\}
\end{aligned}
$$

\section{Results}

\subsection{Variable costs}

Variable costs were projected according to equations (2) and (3), up to 2040 as illustrated in Figure 8 and Figure 9. Base values for 2013, for fuel tax, extra variable costs and $\mathrm{CO}_{2}$ emissions costs, are presented below in Table 6, assuming growth indicators as those included in Table 3.

Table 6 Additional variable costs for 2013

\begin{tabular}{lcccc}
\hline & Tax $(€ / M W h)$ & $\begin{array}{c}\text { Extra variable } \\
\text { costs }(€ / M W h)\end{array}$ & $\begin{array}{c}\mathrm{CO}_{2} \text { emissions trading } \\
\text { system costs }(€ / M W h)\end{array}$ & Fuel cost \\
\hline Crete & 29.40 & 1.6 & 3.37 & $109 \$ / \mathrm{bbl}$ \\
Rhodes & & 0.41 & & $781.7 € / \mathrm{tn}$ \\
Others & 3.325 & & \\
\hline
\end{tabular}


Figure 8 Variable cost projection from 2015 to 2040-scenario A (see online version for colours)

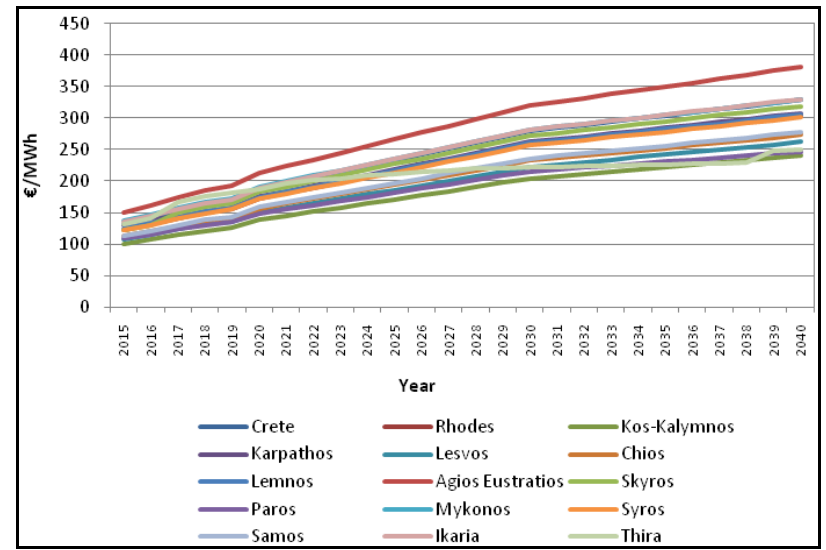

Figure 9 Variable cost projection from 2015 to 2040 -scenario B (see online version for colours)

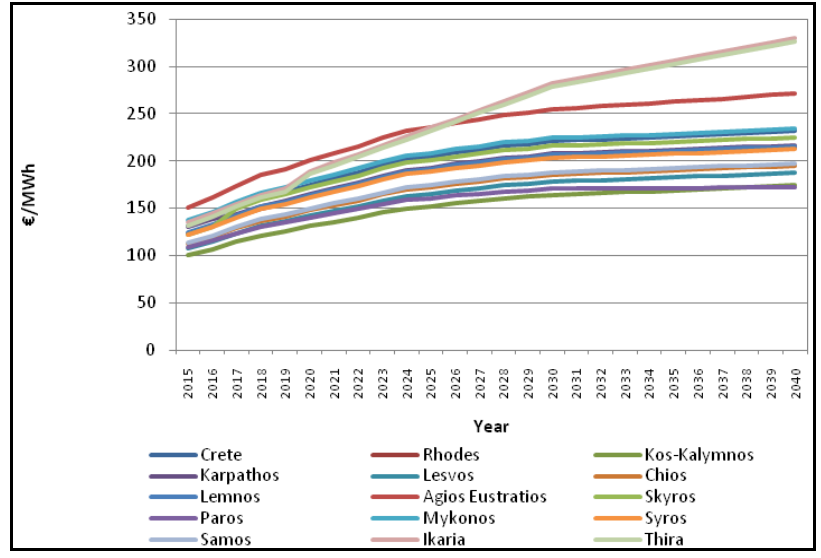

\subsection{Stable costs}

Stable costs consist of two parts, existing capacity costs and capital and interest costs for acquiring new power units [equation (4)]. Stable costs for 2012 and 2013 for each island were used for projecting future costs considering the capacity of each autonomous system as presented in Table 7. Future projections for stable costs per MW follow prices increase trends. 
Table 7 Stable costs for 2012 and 2013 in NII

\begin{tabular}{lcc}
\hline$A P S$ & $2012 k \epsilon / M W$ & $2013 k \epsilon / M W$ \\
\hline Crete & 148.5 & 107.8 \\
Rhodes & 215.5 & 219.8 \\
Kos-Kalymnos & 107.2 & 102.8 \\
Karpathos & 198.0 & 228.2 \\
Lesvos & 120.3 & 100.9 \\
Chios & 87.9 & 43.4 \\
Lemnos & 188.4 & 134.9 \\
Agios Eustratios & 333.3 & 236.5 \\
Skyros & 528.0 & 322.9 \\
Paros & 83.8 & 91.3 \\
Mykonos & 371.0 & 337.4 \\
Syros & 150.4 & 104.9 \\
Samos & 163.1 & 127.2 \\
Ikaria & 335.2 & 274.5 \\
Thira & 27.9 & 176.7 \\
\hline
\end{tabular}

Source: Hellenic Republic (2014c, 2014d); Hellenic Electricity Distribution Network Operator (2014)

Capital cost for acquiring new engines is not included in the annual stable cost per MWh projection in order to avoid high fluctuations among years, also power stations upgrade costs are not mandatorily added to PSO costs. Table 8 includes requirements for new capacity and costs, which are equal to 2.63 billion Euros and 1.80 billion Euros for Scenarios A and B respectively. As a consequence of peak demand diversification, North Aegean islands and Skyros present the highest discrepancy between the two scenarios.

The requirement for new power stations assuming a mix of ICE and gas turbines was projected in Figure 10 and Figure 11. The upgrade plan was conducted following the retirement schedule (Table 4) and peak demand projections as estimated in Scenarios A and $\mathrm{B}$.

Figure 10 Stable costs per MWh from 2015 to 2040 - scenario A (see online version for colours)

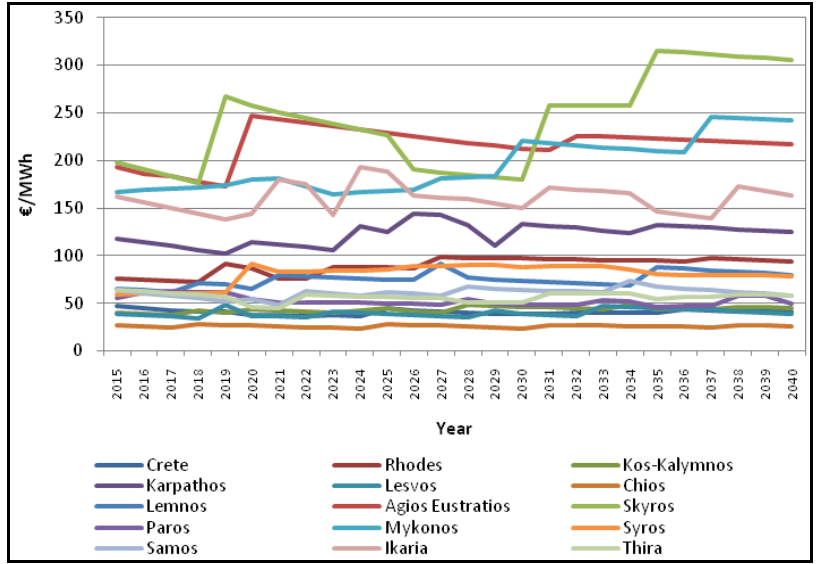


Figure 11 Stable costs per MWh from 2015 to 2040 - scenario B (see online version for colours)

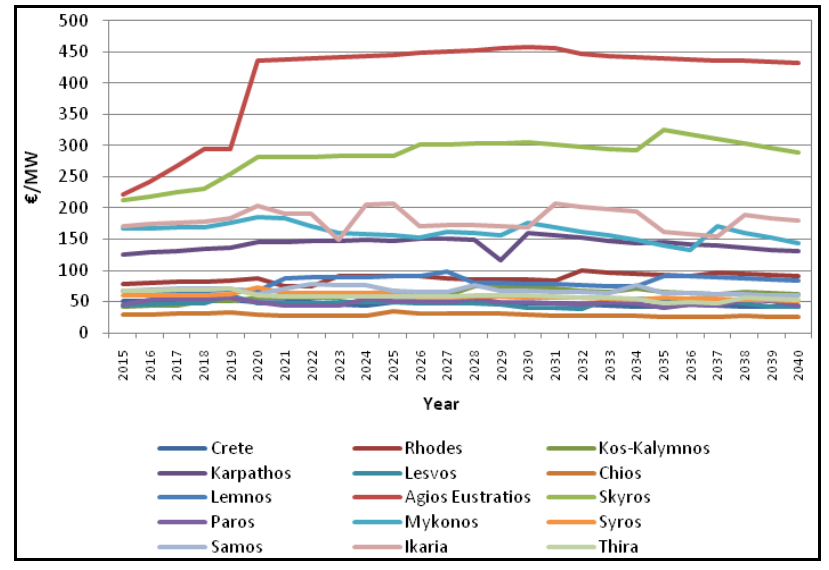

Table 8 Total costs for power stations upgrade

\begin{tabular}{|c|c|c|c|c|c|c|c|}
\hline \multicolumn{8}{|c|}{ Scenario A } \\
\hline & \multicolumn{2}{|c|}{2020} & \multicolumn{2}{|c|}{2030} & \multicolumn{2}{|c|}{2040} & \multirow{2}{*}{$\begin{array}{l}\text { Total costs } \\
\quad \text { mil } €\end{array}$} \\
\hline & $I C E$ & $\begin{array}{c}\text { Gas } \\
\text { turbine }\end{array}$ & $I C E$ & $\begin{array}{c}\text { Gas } \\
\text { turbine }\end{array}$ & $I C E$ & $\begin{array}{c}\text { Gas } \\
\text { turbine }\end{array}$ & \\
\hline Crete & 300 & 0 & 150 & 650 & 250 & 130 & $1,245.6$ \\
\hline Rhodes & 0 & 0 & 110 & 1165 & 20 & 0 & 245.3 \\
\hline Kos-Kalymnos & 20 & 0 & 100 & 50 & 25 & 20 & 222.5 \\
\hline Karpathos & 0 & 0 & 16.5 & & 14 & & 45.8 \\
\hline Lesvos & 0 & 0 & 25 & 40 & 40 & 50 & 142.9 \\
\hline Chios & 0 & 18 & 34 & 25 & 31 & 30 & 152.3 \\
\hline Lemnos & 4 & 0 & 16 & 14 & 10 & 0 & 50.2 \\
\hline AgiosEustratios & 0 & 0 & 1 & 0 & 0 & 0.3 & 1.9 \\
\hline Skyros & 0 & 0 & 4 & 0 & 12 & 0 & 24.3 \\
\hline Paros & 10 & 20 & 10 & 30 & 30 & 20 & 120.4 \\
\hline Mykonos & 0 & 0 & 20 & 15 & 15 & 10 & 79.4 \\
\hline Syros & 0 & 0 & 20 & 10 & 20 & 0 & 55.5 \\
\hline Samos & 0 & 0 & 35 & 34 & 29 & 0 & 112.9 \\
\hline Ikaria & 0 & 0 & 19 & & 11.5 & 0 & 45.5 \\
\hline Ios-Thira & 0 & 0 & 20 & & 40 & 30 & 88.2 \\
\hline Total & 334.0 & 38.0 & 580.5 & $2,033.0$ & 547.5 & 290.3 & $2,632.7$ \\
\hline
\end{tabular}


Table 8 Total costs for power stations upgrade (continued)

\begin{tabular}{|c|c|c|c|c|c|c|c|}
\hline \multicolumn{8}{|c|}{ Scenario B } \\
\hline & \multicolumn{2}{|c|}{2020} & \multicolumn{2}{|c|}{2030} & \multicolumn{2}{|c|}{2040} & \multirow{2}{*}{$\begin{array}{l}\text { Total costs } \\
\quad \text { mil } €\end{array}$} \\
\hline & $I C E$ & $\begin{array}{c}\text { Gas } \\
\text { turbine }\end{array}$ & $I C E$ & $\begin{array}{c}\text { Gas } \\
\text { turbine }\end{array}$ & $I C E$ & $\begin{array}{c}\text { Gas } \\
\text { turbine }\end{array}$ & \\
\hline Crete & 200 & 280 & 130 & 100 & 180 & & 830.7 \\
\hline Rhodes & 0 & 0 & 105 & 50 & 70 & 0 & 174 \\
\hline Kos-Kalymnos & 30 & & 50 & 50 & 25 & 20 & 192.5 \\
\hline Karpathos & & & 5 & 20 & 45 & 35 & 27.3 \\
\hline Lesvos & & 20 & 15 & & 35 & 35 & 69.6 \\
\hline Chios & & & 15 & 15 & 13 & 20 & 82.8 \\
\hline Lemnos & & 10 & 14 & & 6 & & 35.2 \\
\hline AgiosEustratios & & & 1 & & 0.2 & & 1.7 \\
\hline Skyros & & & 2 & & 6 & & 12.3 \\
\hline Paros & & 10 & 5 & 30 & 40 & 20 & 100.5 \\
\hline Mykonos & & & 15 & 20 & 15 & 20 & 84.8 \\
\hline Syros & & & 8 & 3 & 25 & & 46.9 \\
\hline Samos & & & 18 & 10 & & 16 & 48.3 \\
\hline Ikaria & & & 12 & & 9 & & 31.3 \\
\hline Ios-Thira & & & 10 & 40 & 25 & & 65.9 \\
\hline Total & 230.0 & 320.0 & 405.0 & 338.0 & 494.2 & 166.0 & $1,803.8$ \\
\hline
\end{tabular}

\subsection{Public service obligation}

Taking into account the generated outcomes for variable and stable cost projections and assumptions included as indigenous inputs in equation (1), PSO fees were calculated, considering PGAE values as of $2013(70.5 € / \mathrm{MWh})$. The outcomes of the four scenarios, included in Table 9, are illustrated in Figure 12 to Figure 15. The total cost for public service obligation for the included islands is expected to be 39.09 billion Euros for the period 2015-2040 in Scenario A1, whereas a sensitivity analysis on oil fuel prices proved that the total PSO fee could be reduced by $26 \%$ and reach 28.81 billion Euros. In Scenario B1, while decreasing the overall power generation, although global oil prices remain high, cost is estimated to decrease to 27.80 billion Euros. The most optimistic scenario in terms of cost impact shows that the PSO drops to 20.54 billion Euros almost $47 \%$ reduction compared to Scenario A1. In line with these scenarios, it is evident that electricity demand has a higher impact on future costs than oil prices. 
Table 9 Total PSO charges in NII for Scenario A1, A2, B1 and B2

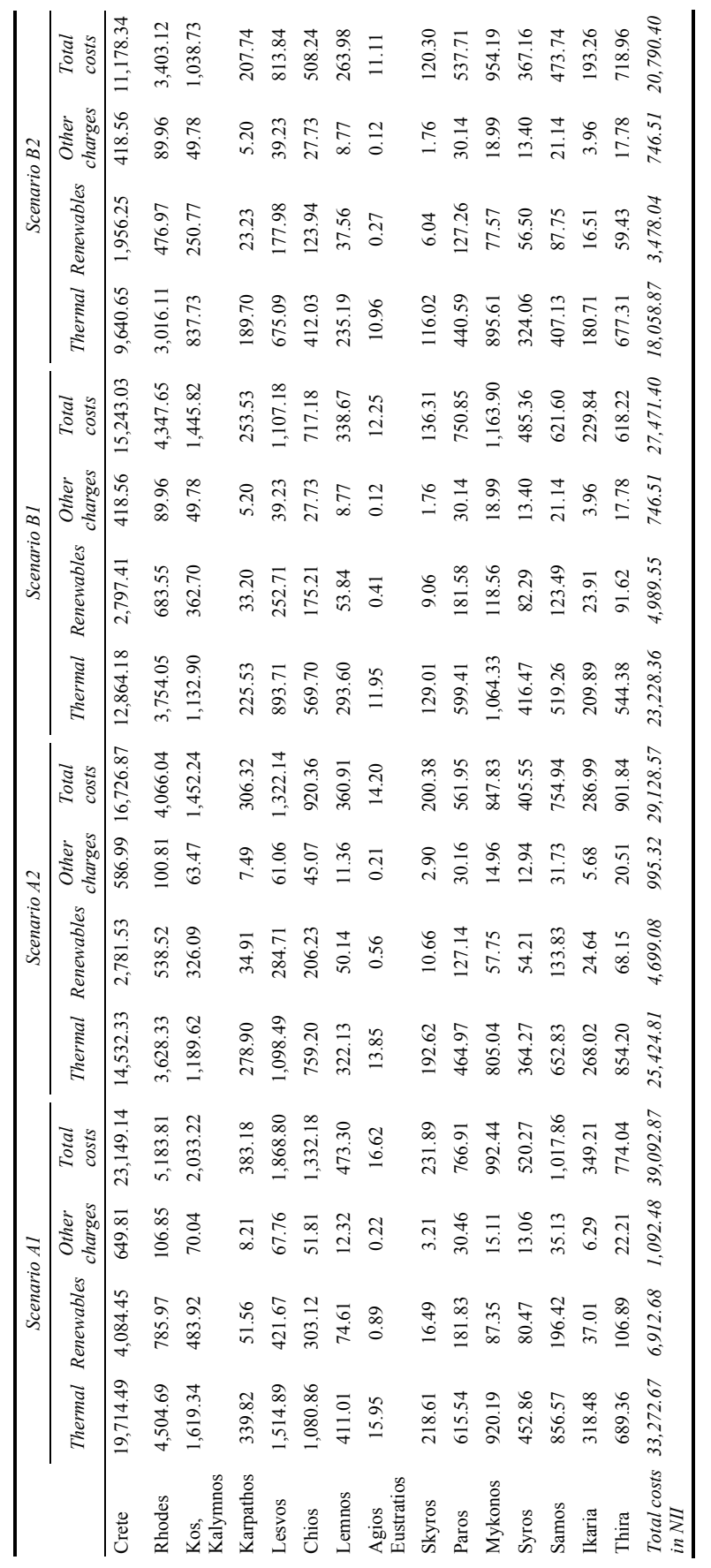


Figure 12 PSO costs from 2015 to 2040-scenario A1 (see online version for colours)

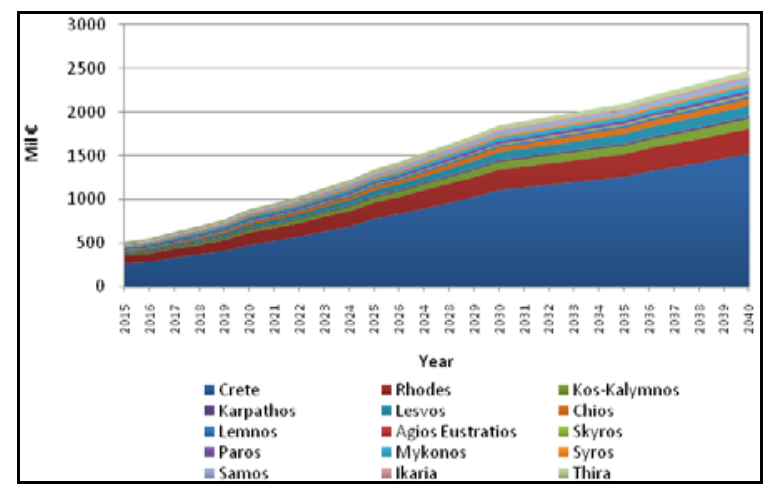

Figure 13 PSO costs from 2015 to 2040-scenario A2 (see online version for colours)

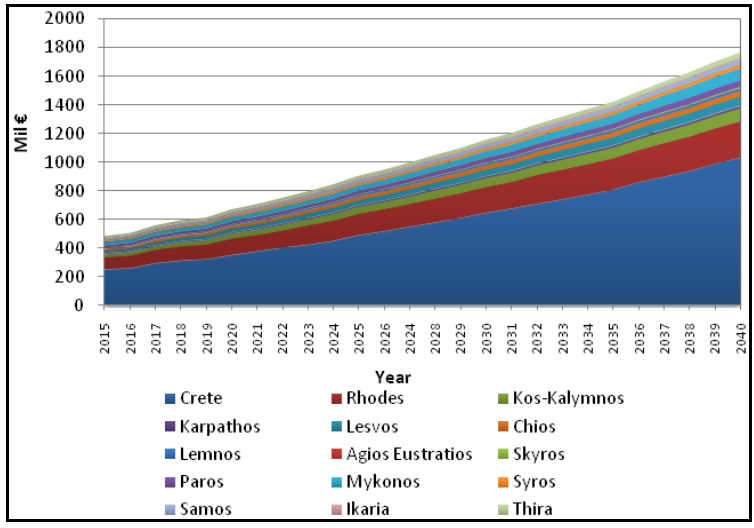

Figure 14 PSO costs from 2015 to 2040-scenario B1 (see online version for colours)

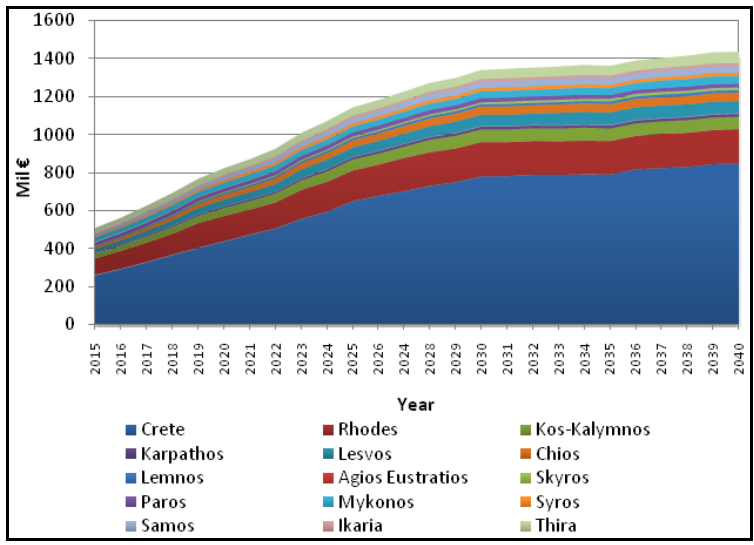


Figure 15 PSO costs from 2015 to 2040-scenario B2 (see online version for colours)

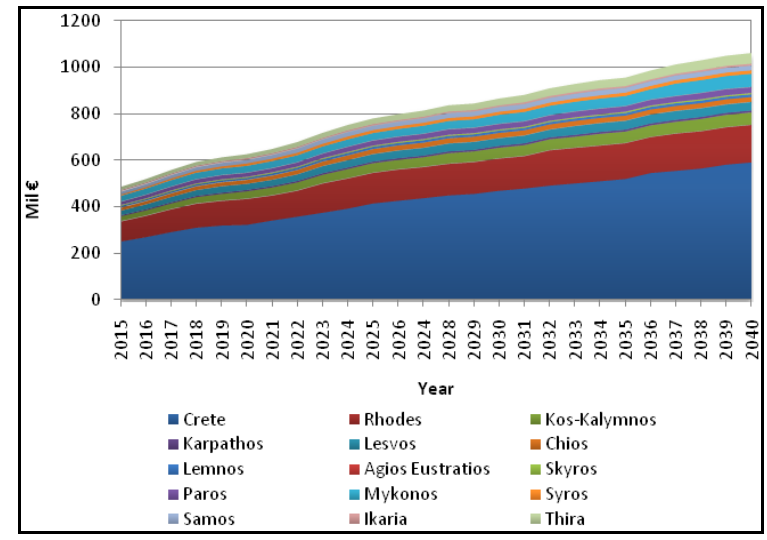

\subsection{Economic benefits from the interconnection}

The analysis and costs' comparison confirm that the interconnection scenario demonstrates a feasible option to reduce power generation costs and increase energy security in the area of the Aegean Sea. Additional costs for maintaining a minimum level of power generation in the islands were estimated for each cluster of islands according to their interconnection date.

\subsubsection{Interconnection of the Cycladic islands $\rightarrow 2017$}

The interconnection configuration meets the requirement for the $\mathrm{N}-1$ criterion and the nominal capacity of the cable can supply demand loads including renewable energy loads. Local power generation following 2017 will remain in minor levels in order to meet Naxos power requirements and following 2025 power stations will terminate their operation. Costs for maintaining a minimum capacity of power stations in inactive condition for energy security reasons were assumed to be $80 \%$ of the expected expenses of the remained equipment until 2025 and following that the rate decreased to $50 \%$ (Independent Power Transmission Operator, 2013).Results for Scenario A \& B, following the year of 2025, including only stable costs present no significant diversification, since no power stations upgrade is required.

\subsubsection{Expansion of Cyclades interconnection $\rightarrow 2020$}

Thira and Ios interconnection with $2 * 140$ MVA submarine cables as proposed, secures smooth power supply almost in any circumstances. As such, following 2020, stable costs have been calculated considering $80 \%$ of expenses for the remaining capacity until 2025 and afterwards 50\%.Outcomes among A1, A2, B1, and B2 cases showed negligible differences, as until 2025 oil fuel prices present minor discrepancies and no unit upgrade is included. 


\subsubsection{Interconnection of Crete $\rightarrow 2020$}

Since the most prominent interconnection scenario is B1 $(2 * 500 \mathrm{MW})$, the back-up plan proposed in this study suggests the operation of oil-fired units able to meet $90 \%$ of the annual peak demand minus 500MW, the nominal capacity of each cable, in case one of the two submarine cables is damaged. Crete is driven by high demand increase, where the interconnection cannot meet power requirements even if the interconnection is completely functional therefore; new power stations are included in the upgrade schedule, mainly gas turbines because they can respond faster to any demand fluctuation. The analysis, beyond Scenario B1, showed the requirement to immerge a third cable in order to reduce local power generation in Crete.

\subsubsection{Interconnection of North Aegean $\rightarrow 2025$}

According to the NTUA study in 2008 the double submarine cable succeeds to provide $\mathrm{N}-1$ energy security in the North Aegean islands. The local power stations will be completely retired following the first five years of interconnection's life (2030). Projections for redundancy costs estimated equal to $80 \%$ of the remaining capacity between 2025 and 2028 and $50 \%$ for 2029 and 2030 .

\subsubsection{Interconnection of Skyros $\rightarrow 2025$}

As Skyros interconnector will become implemented mainly to serve renewable energy loads from large-scale wind farms licensed on the island (Hellenic Electricity Distribution Network Operator, 2010), no additional costs following 2025 have been included as the N-1 Criterion is guaranteed by the proposed interconnection configuration.

\subsubsection{Interconnection of Dodecanese islands $\rightarrow 2030$}

This interconnection project is supposed to be the final, since Dodecanese islands are relatively remote, including the fact that wind potential of the area is comparatively lower. It is assumed that by 2025 Kos-Kalymnos APS will be shut-down and the geothermal power station from Nisyros will be used, providing a capacity of $40 \mathrm{MW}$. By 2030, Crete will become interconnected with Karpathos and following Rhodes.

Rhodes has to maintain operational $200 \mathrm{MW}(\approx 90 \% * 225 \mathrm{MW})$ of oil-fired station in case Crete connection fails to serve demand loads. Also following 2030, Crete has to add additional $200 \mathrm{MW}$ in order to cover power requirements in Dodecanese islands. Crete and Rhodes are the only two islands which will preserve local power stations in order to meet peak loads in the area, especially during the summer months.

The next table presents aggregative numbers for additional expenses for power generation assuming the BAU case, and the interconnection scenario for cases A1, A2, B1 and B2.In total, savings from islands' interconnection range between 17.82 and 9.73 billion Euros. Overall, it becomes evident that Cyclades and Crete interconnection have a clear advantage of becoming directly implemented. Cyclades, subsequent to their interconnection could save from 1.55 billion Euros (Scenario A1) to 1.15 billion Euros (Scenario B2) of additional costs. Cyclades II, prove to be feasible with profits ranging between 346.84 and 190.16 million Euros. For Crete, 11.35 billion Euros are avoided in Scenario A1 and 7.71 billion Euros in B2. 
Table 10 Total costs for BAU and interconnection cases for Scenarios A1, A2, B1 and B2

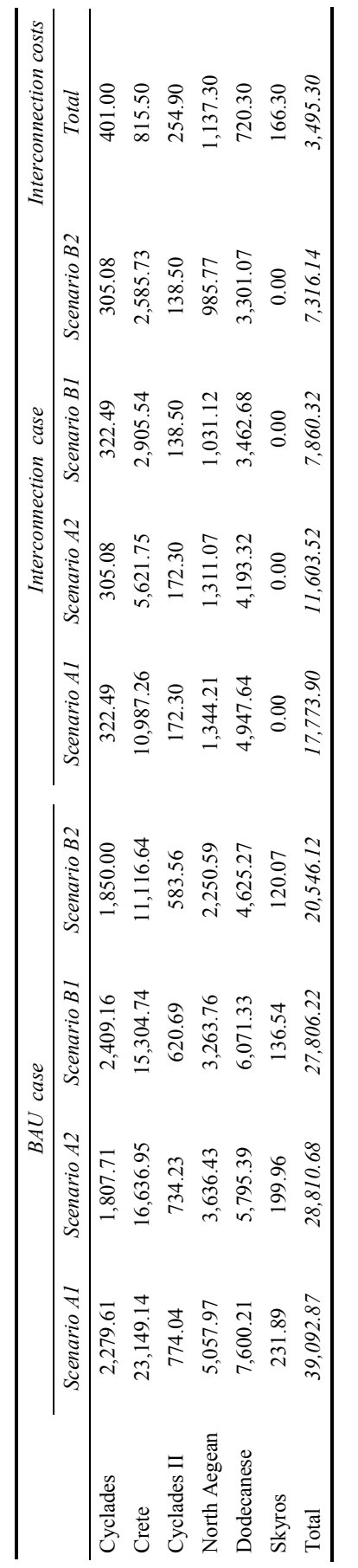


North Aegean has a relatively high interconnection cost which leads to the conclusion that significant benefits can be attained only in Scenario A, equal to 2.57 billion Euros. For A2 and B1 cases outcomes show profits close to 1 billion Euros, while B2 projects only 127.52 million Euros profit. However, the remarkable wind potential of North Aegean creates an incentive to implement the project even if the high growth - high price scenario is not realised. In the Dodecanese interconnection, the highest benefits arise from the Scenario 1, 1.93 billion Euros for A1 and 1.88 for B1, as costs for maintaining back-up sources continue to preserve high values. Scenarios A2 and B2 show profits lower by $50-70 \%$, due to the reduced oil fuel costs. Both North Aegean Sea interconnection and Dodecanese have to be examined by expanding their projection horizon, as their interconnection schedule is delayed and further potential benefits arise beyond 2040.

Finally, Skyros interconnection from an economic perspective could be judged as unprofitable for Scenario B, with losses of 29.76 to 46.23 million Euros. Nonetheless, this project has to become implemented in parallel with wind energy development.

Figure 16 Total costs for BAU and interconnection cases, from 2015 to 2040, for scenarios A1, $\mathrm{A} 2$, B1 and B2 (see online version for colours)

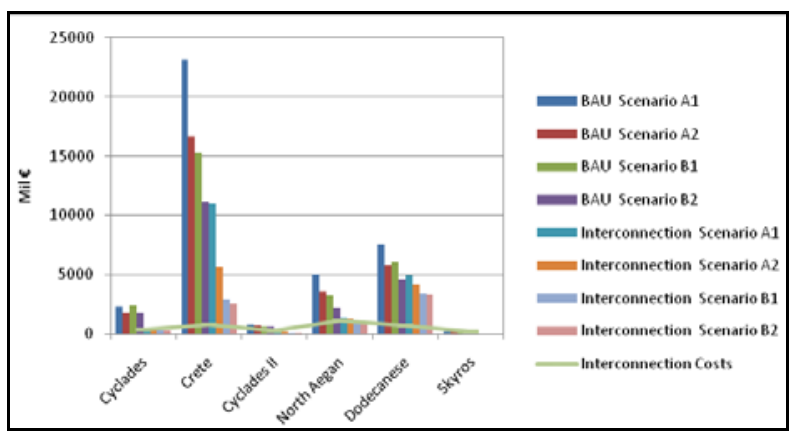

\subsection{Environmental benefits from the interconnection}

\subsubsection{Carbon emissions projections by 2040}

Currently, the area of Aegean Sea emits high levels of carbon dioxide $\left(\mathrm{CO}_{2}\right)$ emissions. In 2012, power generation emissions from NII were recorded to be approximately 4 million tonnes. This amount is equal to $5 \%$ of the total carbon emissions in Greece (Eurostat, 2014).

According to the IPCC methodology, the assumed carbon intensity for oil is $73.3 \mathrm{kgCO}_{2} /$ GJfuel (Blanco et al., 2014). Considering a net efficiency factor of $30 \%$ for oil thermal power plants, carbon intensity for autonomous power systems is estimated to be $0.88 \mathrm{tnCO}_{2} / \mathrm{MWh}$. Carbon emissions projections from APS from 2015 to 2040 are presented in Figure 17, for all the islands included in the interconnection plans. The total cumulative amount of carbon emissions that would be produced in the BAU case, if the autonomous power systems continue their operation on the islands was found to be 155.57 mil tonnes for the high scenario and 107.13 mil tonnes for the low. 
Figure $17 \mathrm{CO}_{2}$ emissions in NII from 2015 to 2040-BAU case, scenario A (see online version for colours)

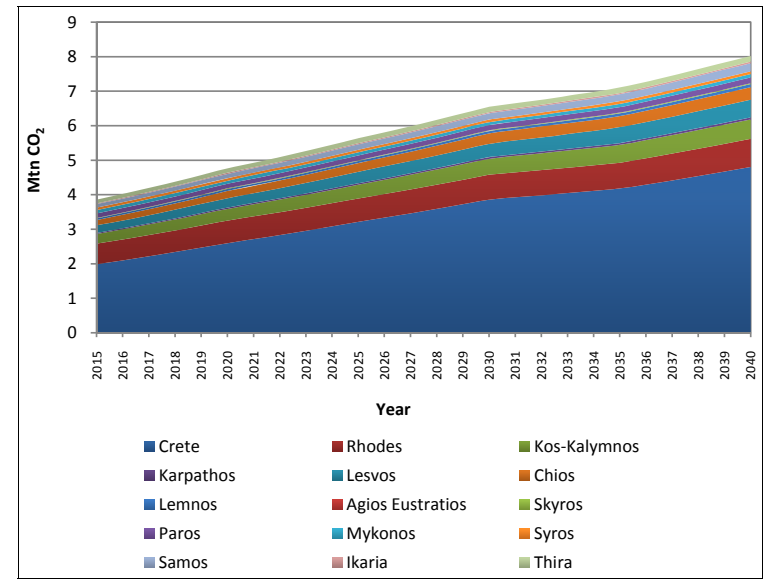

Figure $18 \mathrm{CO}_{2}$ emissions in NII from 2015 to 2040-BAU case, scenario B (see online version for colours)

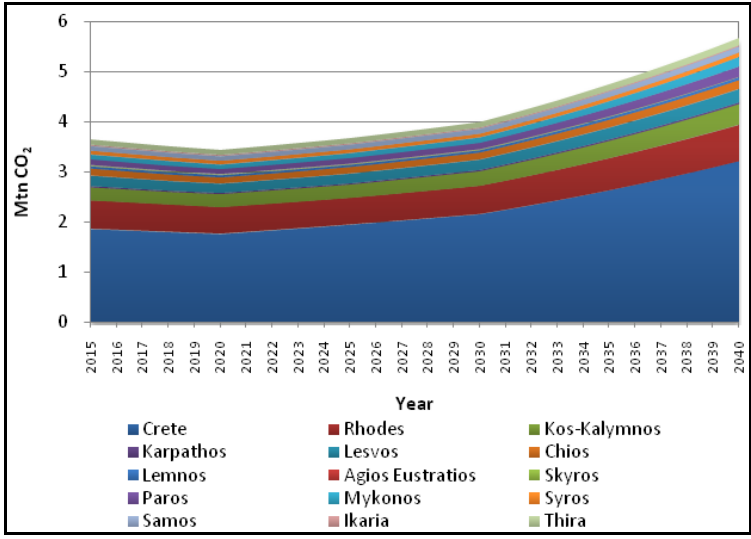

Following the interconnection, the autonomous power systems will shut down and the primary electricity source will be replaced with electricity imports mainly from lignite and gas power stations located in the mainland. The carbon intensity of the Greek interconnected electrical system was estimated to be $0.71 \mathrm{tn} / \mathrm{MWh}$ (IEA, 2014), with projections to decrease more, as $600 \mathrm{MW}$ of lignite power stations will be gradually retired and replaced by nearly $370 \mathrm{MW}$ of natural gas and $125 \mathrm{MW}$ of large hydro power stations (Independent Power Transmission Operator, 2014b).Without considering the positive impact of renewable energy penetration after the interconnection, it is estimated a reduction of 29.9 mil $\mathrm{tnCO}_{2}$ in Scenario A and 20.6 mil $\mathrm{tnCO}_{2}$ in Scenario B, from replacing oil power generation with electricity mix imports. 


\subsubsection{Contribution of renewable energy development to carbon emissions reduction}

It is anticipated a vast increase in renewable energy projects as during the previous years, several private sector companies issued the required licenses and permits and they are pending the implementation of the interconnections in order to initiate the construction of RES projects.

Table 11 presents the projected capacity of new RES installations in the islands for five milestone years 2020, 2025, 2030, 2035 and 2040 with the precondition, interconnection plans to become implemented. These numbers are collected from the following sources: the National Technical University of Athens (2008), National Technical University of Athens (2006) and the Independent Power Transmission Operator (2013). RES development plan is conducted based on the maximum limit of wind installations, cables' nominal capacity, wind potential on the islands, available land areas, environmental conditions, national and European targets for renewable energy share in 2020 and 2030 as well as feasibility studies related to such investments. The previous studies have not taken into account the current economic recession, which alongside other financial, administrative and technical issues have postponed the implementation of the interconnections. At this point, we should also mention additional challenges related to the social acceptance for such large-scale projects, which have to be addressed. For the above reasons, estimations for RES development have been slightly rescheduled in order to integrate existing and future probable delays. By 2040, estimations show $2.46 \mathrm{GW}$ of wind energy installations in the NII area.

Table 11 Renewable energy development in islands following the interconnections

\begin{tabular}{|c|c|c|c|c|c|c|}
\hline \multirow{2}{*}{$\begin{array}{l}\text { Region to be interconnected } \\
\text { Year }\end{array}$} & \multirow[b]{2}{*}{2015} & \multicolumn{5}{|c|}{$R E S(M W)$} \\
\hline & & 2020 & 2025 & 2030 & 2035 & 2040 \\
\hline Existing RES installations & 452 & 452 & 452 & 452 & 452 & 452 \\
\hline Cyclades islands & & 60 & 160 & 200 & 230 & 250 \\
\hline Expansion of Cyclades interconnection (Ios and Thira) & & & 20 & 30 & 50 & 60 \\
\hline \multicolumn{7}{|l|}{ Crete } \\
\hline Scenario A & & & 200 & 400 & 600 & 1,000 \\
\hline Scenario B & & & 150 & 300 & 400 & 500 \\
\hline Scenario C & & & 200 & 400 & 600 & 1,000 \\
\hline North Aegean & & & & 650 & 950 & 1,100 \\
\hline Chios & & & & 150 & 250 & 250 \\
\hline Lesvos & & & & 250 & 300 & 350 \\
\hline Ikaria & & & & 25 & 50 & 50 \\
\hline Samos & & & & 75 & 100 & 150 \\
\hline Lemnos & & & & 150 & 250 & 300 \\
\hline Dodecanese islands (among them) & & & & 50 & 55 & 65 \\
\hline Crete and Dodecanese islands (scenario B) & & & & & 450 & 650 \\
\hline Skyros island & & & & 200 & 333 & 400 \\
\hline Total RES integration & 452 & 512 & 782 & 1,882 & 2,465 & 2,912 \\
\hline
\end{tabular}


Power generation from renewable energy projects in the area and principally wind will manage to meet $25 \%$ and $34.7 \%$ of electricity supply for scenarios A and B respectively, in 2020. This rate will be increased to $38 \%$ in 2025 in Scenario A and $49 \%$ in Scenario B and following 2030, there will be power availability of electricity exports in the mainland on an annual basis (imports-exports) for Scenario B. In 2040, in Scenario A, 84.7\% of annual demand will be covered by renewable energy, whereas in Scenario B, RES share in the electricity mix will increase to $100 \%$ and more than $1,125 \mathrm{GWh}$ will be available for exports to the mainland (Figure 19). Such high levels of sustainable integration into the system could exemplify Greek islands as renewable energy exporters adding extra value to the interconnection project.

Figure 19 Total power generation for scenarios A and B and renewable energy generation from 2015 to 2040 (see online version for colours)

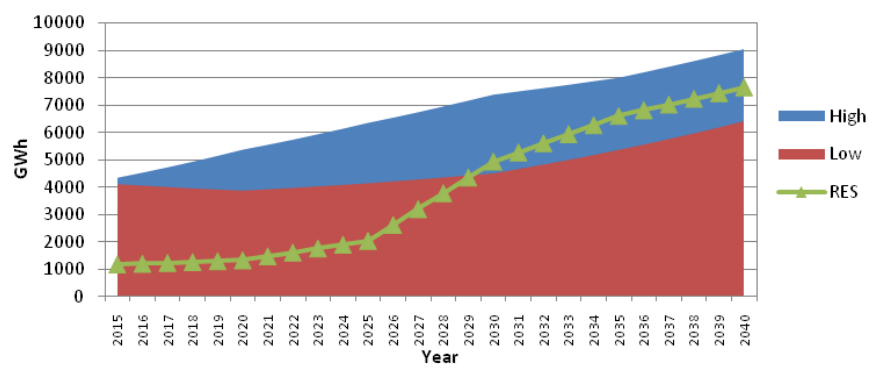

Overall, the sustainable energy increase will contribute to emissions reduction for the period 2015-2040, with 89.26 million tonnes in the BAU case and 50.65 million tonnes following the interconnections and replacement of oil with electricity imports from the mainland. Subsequent to the interconnection and RES development, the cumulative carbon footprint will be reduced to 76.02 million tonnes in 2040 for Scenario A and 36.9 million tons for Scenario B, equivalent to $51.1 \%$ and $65.5 \%$ decrease compared to the scenario of the continuation of APS use.

\section{Conclusions}

In this paper we investigated the economic and environmental benefits from the interconnection of the non-interconnected Greek islands. The economic drivers for the implementation of this project include fuel costs, taxes, $\mathrm{CO}_{2}$ emissions costs, capital costs, upgrade equipment costs and other expenses. Following the interconnection of Cyclades, North Aegean, Crete, Dodecanese and Skyros islands, the economic profit for the Greek state could reach 17.82 billion Euros for Scenario A1 and 9.73 billion Euros for Scenario B2, considering a projection time horizon between 2015 and 2040. The upgrade costs for new engines for power stations is estimated to be between 2.63 and 1.80 billion Euros for Scenarios $\mathrm{A}$ and $\mathrm{B}$ respectively. Cyclades and Crete interconnection prove to be the two most feasible projects in all scenarios. Also, results show that Crete and Dodecanese islands have potential to increase the economic benefit from eliminating local thermal generation, with the prerequisite to enhance their current interconnection plans. 
Besides economic drivers, Greece will enjoy important environmental benefits from the interconnection, which will assist the country to reach its European environmental targets for 2020 and 2030. The Aegean NII following their interconnection and the gradual retirement of the old oil thermal power units will manage to reduce their carbon footprint at 76.02 million tonnes in Scenario A and 36.9 million tonnes in Scenario B by 2040, compared to 155.57 million tonnes, 107.13 million tonnes respectively assuming the continuation of APS operation. This is attributed to electricity imports from the national grid system in the mainland and principally due to the expansion of RES to $84.7 \%$ share of the power demand by 2040 in Scenario B and $119 \%$ in Scenario A, allowing for electricity exports to the NGS in the mainland. Overall, this study shows that if economic and social barriers are successfully addressed the interconnection of the Greek islands could bring to Greece economic prosperity, energy liberalisation, security, in parallel with environmental protection, and will highlight the exceptional renewable energy potential of the area of the Aegean Sea.

For future work, our objective is to analyse, through the adoption of a more robust and analytical approach, including scenario development and parametrical sensitivity analysis, the impact of high renewable energy integration in the interconnected islands to the Greek energy system. Moreover, investigation of additional benefits from RES expansion in the islands in order to eliminate social controversies around renewable energy plants will be further analysed.

\section{References}

Argyriou, A. (2013) European Emissions Trade System: An Inefficient Measure Towards the Swift to Clean Energy, Avgi [online] http://www.avgi.gr/article/694181/

europaiko.sustima.emporias.aerion.rupon.anapotelesmatiko.ergaleio.gia.ti.strofi.stin.kathari.en ergeia (accessed 5 January 2015).

Bank of Greece (2015) Monthly Infation Factors for Greece (1959-2015) [online] http://www.bankofgreece.gr (accessed 11 January 2015).

Blanco, G. et al. (2014) 'Drivers, trends and mitigation', in Edenhofer, O.R., Pichs-Madruga, Y. and Sokona, E.F. (Eds.): Climate Change 2014: Mitigation of Climate Change. Contribution of Working Group III to the Fifth Assessment Report of the Intergovernmental Panel on Climate Change, Cambridge University Press, Cambridge, UK and New York, NY, USA.

European Commission (2009) The 2020 Climate and Energy Package [online] http://ec.europa.eu/ clima/policies/package/index_en.htm (accessed 26 March 2015).

European Commission (2014) 2030 Framework for Climate and Energy Policies [online] http://ec.europa.eu/clima/policies/2030/index_en.htm (accessed 26 March 2015).

European Union (2003) Directive 2003/54/EC of the European Parliament and the Council of 26 June 2003 Concerning Common Rules for the Internal Market in Electricity and Repealing Directive 96/92/ECle, Brussels [online] https://www.energy-community.org/pls/portal/docs/ 36275.PDF (accessed 22 March 2015).

Eurostat (2014) Greenhouse Gas Emissions [online] http://appsso.eurostat.ec.europa.eu/nui/ show.do?dataset=env_air_gge\&lang=en (accessed 12 January 2015).

Hatziargyriou, N., Papathanasiou, S. and Vitellas, I. (2012) Energy Management in the Greek Islands, pp.1-8, Cigre, Paris, France.

Hellenic Electricity Distribution Network Operator (2010) Interconnection of the islands in the Aegean Sea (Part A-General Planing) [online] http://www.desmie.gr/fileadmin/user upload/ Files/study/AIGAIA_DIASYNDESI_FASI_A_PERILIPSI.pdf (accessed 18 January 2015). 
Hellenic Electricity Distribution Network Operator (2013a) Monthly Reports of RES \& Thermal Units in the Non-Interconnected Islands, January [online] http://www.deddie.gr/en/thematatou-diaxeiristi-mi-diasundedemenwn-nisiwn/miniaia-deltia-ape-kai-thermikis-paragwgis-stami-diasundedemena-nisia (accessed 1 February 2015).

Hellenic Electricity Distribution Network Operator (2013b) Statistical Database for Power Generation in the NII (2009-2013), Athens, Greece.

Hellenic Electricity Distribution Network Operator (2014) Monthly reports of RES \& thermal units in the non-Interconnected Islands, December [online] http://www.deddie.gr/en/themata-toudiaxeiristi-mi-diasundedemenwn-nisiwn/miniaia-deltia-ape-kai-thermikis-paragwgis-sta-midiasundedemena-nisia (accessed 1 February 2015).

Hellenic Republic - Ministry of Environment Energy and Climate Change (2013) Hellenic Republic, New FIT for Solar Installations, Installed After the 1rst of June/2013 [online] http://www.ypeka.gr/Default.aspx?tabid=785\&sni\%5B524\%5D=2401\&language=el-GR (accessed 25 November 2014).

Hellenic Republic (1999) Law 2773 - Liberilization of the Greek Market and Energy Policy Regulations, Athens, Greece.

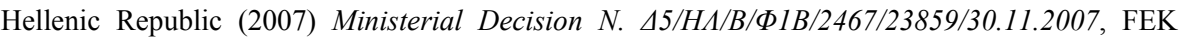
2353, Issue B, Greece [online] http://www.et.gr/idocs-nph/search/pdfViewerForm.html?args= 5C7QrtC22wFNA1ry4K61p3dtvSoClrL8Xne5rO2Ypm64ndCieBbLVuJInJ48_97uHrMts-zFz eyCiBSQOpYnT00MHhcXFRTsY0Ec1IC5cWYNTeFBD9A2xlWxKBCC155zMrB6TmC2Ew (accessed 22 August 2015).

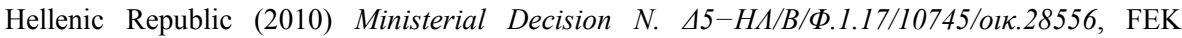
2095/2010, Issue B, Greece [online] http://www.et.gr/idocs-nph/search/pdfViewerForm.html? args=5C7QrtC22wEbA_BZxkczbHdtvSoClrL8_xWC9HhzIh4liYHTRwL0-OJInJ48_97uH rMts-zFzeyCiBSQOpYnT00MHhcXFRTsF-yairBZ9tLRA2ZyS8I5GMjfZnpajPJr0 DUB0HENa8E (accessed 11 November 2014).

Hellenic Republic (2011a) Law 4001 - Electicity Market Operation and Natural Gas, Research and Production, Gas Transmission Grid and Other Regulations, Athens, Greece.

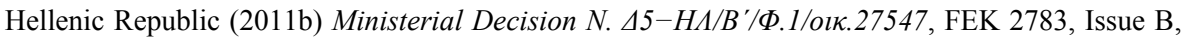
Greece [online] http://www.et.gr/idocs-nph/search/pdfViewerForm.html?args=5C7QrtC22w FYAFdDx4L2G3dtvSoClrL8XZoNjnH3CZi4ndCieBbLVuJInJ48_97uHrMts-zFzeyCiBSQO pYnT00MHhcXFRTsN_2UlrlNG4QuR078_6kzIIMbEmnX36jWq4fYey9eCMo. (accessed 18 November 2014).

Hellenic Republic (2012) Law 4067 - The New Urban Design Regulations and Other Policies, Athens, Greece.

Hellenic Republic (2013) Ministerial Decision N. 1/1289/9012, FEK 1103, Issue B, Greece [online] http://www.deddie.gr/Documents2/Fotovoltaika/ФEK 1103_2-5-2013.pdf (accessed 21 November 2014).

Hellenic Republic (2014a) Ministerial Decision N. 39/2014, Non-interconnected Islands Operation Code, FEK 304, Issue B, Greece [online] http://www.deddie.gr/Documents2/MDN/ ФEKB'30411022014K $\Omega \Delta I K A \Sigma \Delta I A X E I P I \Sigma H \Sigma M \Delta N$.pdf (accessed 17 February 2015).

Hellenic Republic (2014b) Ministerial Decision N. 138/2014, FEK 885, Issue B, Greece: [online] http://gr/wp-content/uploads/2014/05/FEK_885_09-04-2014_tB.pdf (accessed 21 July 2015).

Hellenic Republic (2014c) Ministerial Decision N, 313/2014, FEK 1836, Issue B, Greece [online] http://www.et.gr/idocs-nph/search/pdfViewerForm.html?args=5C7QrtC22wEc63YDhn5AeXd tvSoClrL8t3VVDiksYNsfP1Rf9veiteJInJ48_97uHrMts-zFzeyCiBSQOpYnTy36MacmUFC x2ppFvBej56Mmc8Qdb8ZfRJqZnsIAdk8Lv_e6czmhEembNmZCMxLMtV3-cppbEQmLj6h XvYDyWdbPQU1PL6_Bq_xP6C1rf05a (accessed 3 January 2015; 16 January 2015).

Hellenic Republic (2014d) Ministerial Decision N. 357/2014, FEK 1873 , Issue B, Greece, pp.23627-23642 [online] http://www.et.gr/idocs-nph/search/pdfViewerForm.html?args=5C7Q rtC22wEc63YDhn5AeXdtvSoClrL8HrWp6VkYB5y4ndCieBbLVuJInJ48_97uHrMts-zFzeyC iBSQOpYnT00MHhcXFRTsm0kfWRq_UrzlAVseuqZNypMCQE7sMk3xe5eY0PmYFWk (accessed 21 July 2015). 
Hellenic Statistical Authority (2011) Demographic and Social Characteristics of the Resident Population of Greece [online] http://www.statistics.gr/portal/page/portal/ESYE/PAGEthemes?p_param $=A 1602 \& r \_$param $=S A M 01 \& y \_$param $=2011 \_00 \&$ mytabs $=0 . \quad($ accessed 10 September 2014).

IEA (International Energy Agency) (2014) CO2 Emissions from Fuel Combustion: Highlights 2014 [online] http://www.iea.org/media/statistics/IEA_HeadlineEnergyData_2015.xlsx (accessed 16 January 2015).

IEA and OECD (2014) World Energy Outlook-WEO, International Energy Agency, Paris, France.

Iliadou, E.N. (2009) 'Electricity sector reform in Greece', Utilities Policy, Vol. 17, No. 1, pp.76-87 [online] http://dx.doi.org/10.1016/j.jup.2008.03.002 (accessed 4 March 2015).

Independent Power Transmission Operator (2013) Initial Ten Year Development Plan for the Transmission System (2014-2023) [online]

http://www.admie.gr/uploads/media/DPA_2014-2023_Prokatarktiko_Schedio.pdf (accessed 5 January 2015).

Independent Power Transmission Operator (2014a) Press Release-Contract Agreement for the Interconnection of Cyclades with the Main System [online] http://www.admie.gr/anakoinoseis/ deltia-typoy/deltio-typoy/article/1581/ (accessed 5 January 2015).

Independent Power Transmission Operator (2014b) Ten Year Development Plan for the Transmission System (2014-2023) [online] http://www.admie.gr/uploads/media/DPA_20142023_Prokatarktiko_Schedio.pdf (accessed 5 January 2015).

Maroulis, G. (2013) Electricity Grid Issues in Greece, RES Legal, European Comission [online] http://www.res-legal.eu/search-by-country/greece/tools-list/c/greece/s/rese/t/gridaccess/sum/140/lpid/139/(assessed 2 February 2015).

Ministry of Reconstruction of Production Environment and Energy, European Emissions Trade System (2015) Climate Change [online] http://www.ypeka.gr/Default.aspx?tabid=456\&locale $=$ en-US\&language $=$ el-GR (accessed 13 March 2015).

National Technical University of Athens (2006) Initial Strategic Planning for the Interconnection of the Non-Interconnected Islands, NTUA, Athens, Greece.

National Technical University of Athens (2008) Final report - Strategic plan for the interconnection of non-interconnected islands to the Regulatory Authority for Energy of the Hellenic Republic [online] http:/www.rae.gr/site/file/categories_new/about_rae/activity/ research/report9? $\mathrm{p}=$ files\& $\mathrm{i}=0$ (accessed 18 September 2015$)$.

Panteri, E. and Sardi, K. (2010) Market Organization of Autonomous Electricity Systems, Regulatory Authority for Energy of the Hellenic Republic, European Union, Sustainable Energy Week, Brussels, Belgium.

Papadopoulos, M. et al. (2006) Strategic Plan for Interconnecting Autonomous Island Power Networks-Presentation, Athens, Greece.

Public Power Corporation (2014) Data for Autonomous Power Systems Power Stations [online] http://www.dei.gr/ (accessed 5 January 2015).

Regulatory Authority for Energy, Public Power Corporation and Independent Power Transmission Operator, (2008) Study for the Interconnection of Cyclades with the Mainland, IPTO, Athens, Greece.

Regulatory Authority for Energy (2013) Non-Interconnected Islands [online] http://www.rae.gr/site/categories_new/electricity/market/mdn.csp (accessed 11 February 2015).

Regulatory Authority for Energy (2014) Methodology for the Calculation of the Subsidization for the Coverage of Expenses for the Public Service Obligation in the NII, pp.1-6 [online] http://www.rae.gr/site/file/categories_new/about_rae/actions/decision/2014/2014_A0014?p=fil es\& $\mathrm{i}=0$ (accessed 2 August 2015). 
Regulatory Authority for Energy, Public Power Corporation and Independent Power Transmission Operator (2011) Study for the Development of the Transmission System of CreteInterconnection with the Main System [online] http://www.admie.gr/fileadmin/user_upload/ Files/study/MELETI_DIASYNDESIS_TIS_KRITIS_EKTENIS_PERILIPSI.pdf (accessed 12 March 2015; 11 February 2015).

Tsakiris, F.R. (2010) Energy Development in the Non-Connected Islands of the Aegean Sea, Internship report, Orkustofnun-National Energy Authority, Reykjavik, Iceland [online] http://www.os.is/gogn/Skyrslur/OS-2010/OS-2010-08.pdf (accessed 8 July 2014).

US Energy Information Administration (2016) Spot Prices for Crude Oil and Petroleum Products, [online] http://www.eia.gov/dnav/pet/pet_pri_spt_s1_m.htm (accessed 14 January 2016).

\section{Notes}

$\mathrm{CO}_{2}$ costs are included.

2 Mega volt ampere.

3 In this study, currency rate between Euro and Dollar is assumed to remain equal on average in the following decades. 